\title{
Sosyal sermaye, güven ve yalnızlık açısından yaşlıların yaşam deneyimleri üzerine nitel bir araştırma
}

\author{
Aylin GÖRGÜN-BARAN"1a, Beril GÜNAYb ${ }^{b}$ Buket BEREKETLİb \& Işll IŞIK ${ }^{b}$ \\ aHacettepe Üniversitesi, Edebiyat Fakültesi, Sosyoloji Bölümü, Ankara / Türkiye \\ bHacettepe Üniversitesi, Sosyal Bilimler Enstitüsü, Sosyoloji Anabilim Dalı YL Programı Öğrencileri \\ ORCID ID: 0000-0003-4221-1941 ORCID ID: 0000-0002-6693-7280 \\ ORCID ID: 0000-0001-8866-8707 ORCID ID: 0000-0002-1773-0339
}

\section{ÖZET}

$\mathrm{Bu}$ araștırma yașlıların sosyal sermayelerine odaklanmıștır. Bu kapsamda araștırmanın temel sorusu; sosyal sermaye kuramı çerçevesinde yașlılar sosyal ilișkilerini nasıl gerçekleștirmekte, kimlerle birlikte olmakta, neler yapmakta, gönüllü ve sivil topluluklara toplumsal katılımları nasıl olmaktadır? Çalıșmanın amacı; katılımcıların aile, akrabalık, arkadașlık, komșuluk ilișkileri ve bu ilișkilerden beklentilerini belirlemek; güven duygusu ve topluma katılım ile sosyo-kültürel faaliyetlerde bulunma durumlarına ilișkin deneyimlerini tespit etmektir. Araștırma nitel bir çalışma olup, Ankara'da ikamet eden 65 yaş ve üzeri 16 katılımcı ile yarı-yapılandırılmış soru formu kullanılarak derinlemesine görüşmeler yoluyla veriler toplanmıștır. Araștırmanın sonuçlarına göre katılımcıların aile ve akrabalarıyla olan ilișkileri olumlu olarak değerlendirilmiș, çocukları ve torunlarının onlar için önemli sosyal ilişki aktörleri oldukları sonucuna varılmıștır. Aile ilișkilerinin ise güvenli bağlarla kurulduğu ve sosyal destek mekanizması olarak katılımcılara yardımcı bir işleve sahip olduğu görülmektedir. Güven ilişkisi kurarken samimiyet ve karşılıklı paylaşımdan mutlu olan katılımcılar, en büyük güven kaynağının aileleri olduğunu belirtmișlerdir. Aile ve komşuluk ilişkilerinin yalnızlıklarını önemli ölçüde giderdiği saptanmıştır. Ayrıca katılımcıların çoğunun toplumsal katılım bakımından çeşitli sebeplerle gönüllü faaliyetlerde yer almadıkları, kurumların sağladığı imkânlardan yararlanmadıkları ve sosyo-kültürel faaliyetlere katılmadıkları sonucuna ulaşılmıştır.

\section{A qualitative study on the life experiences of elderly people in terms of social capital, confidence and loneliness}

\begin{abstract}
This study is focused on social capital of elders. In this context, how elders realize their social relationships in the frame of social capital theory, who elders accompany with, what elders do and how elders participate in volunteer and civil communities are the basic questions of the study. The aim of the study is to determine the experiences of elders related to family, blood kinship, friendship and neighborhood relations of elders, the expectations and confidence feeling, participation in society and social-cultural activities of elders. This is a qualitative research, and the data was collected through depth interviews by using semi-structured question form with 16 participants who were 65 ages and older living in Ankara province. According to the findings of the research, the relationships of elders with their families and relatives are considered positive and it is concluded that the children and grandchildren of elders are the important social relationship actors for elders. It is also found that the family relationships are based on confident links and functional for participants as a social support mechanism. The participants, who are pleased of mutual sincerity and sharing in the establishment of confident relationship, stated that their families are the greatest resource in terms of confidence. It is also determined that family and neighborhood relationships are very important for elimination of loneliness of elders. It is also concluded that most of the participants do not take place in voluntary activities, do not take advantages of organizations and do not participate in socio-cultural activities in terms of social participation.
\end{abstract}

\section{MAKALE GEÇMIȘİ \\ emmuz 202}

ANAHTAR KELIMELER

Yaşlanma, sosyal sermaye, güven, toplumsal katılım, sosyo-kültürel faaliyetler

\section{ARTICLE HISTORY}

Received 30 July 2020

Accepted 09 October 2020

\section{KEYWORDS}

Ageing, social capital, confidence, social participation, socio-cultural activities

1 Sorumlu yazar, e-mail: abaran@hacettepe.edu.tr

Makalenin Kaynak Olarak Gösterimi: Görgün-Baran, A., Günay, B., Bereketli, B., \& Işık, I. (2020). Sosyal sermaye, güven ve yalnızlık açısından yaşlıların yaşam deneyimleri üzerine nitel bir araştırma. Yaşlı Sorunları Araştırma Dergisi (YSAD), 13(2), 72-89. doi:10.46414/yasad.775885

YSAD-EIRJ 2020 / 13(2), 72-89 


\section{GİRIS}

Yașlanma sürecine ilișkin literatürün günümüzde giderek artmaya başladığı görülmektedir. Bunun nedeni küresel ölçekte yașlı nüfusun artması, yașlılık dönemindeki sosyal, psikolojik ve sağlık sorunlarının baş göstermesi ve yaşlılara sunulacak sosyal hizmetlerin ve bakım yükünün maliyetinin yükselmesidir. $\mathrm{Bu}$ olguların araştırılması birçok disiplini gerekli kıldığından gerontoloji ve eleștirel gerontoloji bilimleri ile birlikte sosyoloji, psikoloji, antropoloji, ekonomi, siyaset vb. gibi alanlardaki çalışmalarla yaşlılık ve yaşlanma, interdisipliner bir hale gelmiştir. Yaşlılık döneminde en çok yaşanan problemler sağlığın bozulması, yoksulluk ve gelir düzeyi düşüklügüu, sosyal güvenceden yoksun olma, aile ve diğer sosyal ilişkilerde yaşanan gerginlikler, ihmal ve istismar ile yalnızlık ve güven duygusu, bunama vb. gibi birbirini tetikleyen sorunlardır. Bu çalışma, sosyal sermaye sahipliği ile yalnızlık arasındaki ilişki konusuna odaklanmıştır. Yaşlılık döneminde sosyal ilişskilerin sık dokulu olması yaşlı bireyleri yaşama bağlayan önemli göstergelerdendir. Bu konuda Coleman ve Putnam (Field, 2008) sosyal ilişkilerin sürdürülebilir olmasında güven duymanın önemine değinmekte, insanın hem rasyonalitesini hem de duygularını birbiriyle ilişkilendirerek davranma kapasitesine sahip olduğunu ve bio-psikososyal bir varlık olarak sosyalitesi en yüksek canlı olma özelliği gösterdiğini belirtmektedirler. Sosyal ilişsileri aile, akrabalık, komşuluk, arkadaşlık ve gönüllü kuruluşlarda üyelik ve bu kuruluşların faaliyetlerine katılım biçiminde belirlemek mümkündür. Dolayısıyla insanı sosyal kılan, sosyal ilişkilerini sürdürebilme performansıdır. Sosyalite bireyin bu performansı gösterebilme kapasitesini imlemektedir.

Yaşlanma, içinde çok boyutlu süreçleri barındıran, problemleri ve çözümleri farklı olan toplumsal bir tasarım (Tufan, 2014:6) olarak bir inşa sürecini var kılmaktadır. Bu toplumsal tasarım ve inşa sürecinde her birey, yaşlanmayı farklı şekillerde algılamakta ve deneyimlemektedir. Yaşlılıkta yaşanan fiziksel, sosyal ve ekonomik değişimler farklı yaşlanma hallerini ortaya çıkarmakta ve bir yaşlı heterojenitesinden söz edilmektedir (Loas, 2018). Yaşlı heterojenitesine Bourdieu'nun kültürel sermaye kavramı açısından yaklaşılabilir. Sosyal statü, kültürel sermaye ve sınıf farklılıklarından kaynaklanan çeşitli yaşlı kategorilerinden söz edilebilir. Ancak yaş alma öyle bir konu ki, tüm farklı düzeydeki yaşlıları farklı biçimlerde etkilemekte, zaman zaman yaşlı ayrımcılığı durumlarıyla karşılaşılmaktadır (Görgün-Baran, 2018). Bununla birlikte yaşlı bireyin ekonomik gelirinin iyi olmasına rağmen özellikle sağlı̆̆ının bozulması ve birçoğunun yalnızlık duygusu yaşaması, bu gruptaki yaşlıların sorun yașamasına ve basmakalıp düşüncelere maruz kalmalarına neden olmaktadır. Öte yandan emekli geliri olan ve olmayanlar açısından orta ve alt sınıf yaşlıların gündelik yaşamlarını sürdürmede zorlandıkları görülmekte, sağlık sorunlarının artmasına paralel olarak harcamalarının da artması karşısında yaşlıların sağlık hizmetlerine erișim ve yararlanma olanakları azalmaktadır. Böylelikle yaşlı bireyin sosyal sermayesini kullanma imkânı aile yakınları ile sınırlı kalmakta, topluma katılma, yabancı kültürleri ve ülkesinin farklı kültürel, turistik mekânlarını tanıma ve dolaşma, eğlence amaçlı sosyal ve kültürel faaliyetlerde bulunma gibi etkinliklerden mahrum kaldığı görülmektedir.

Vincent (2014:103), sermayenin yalnızca bir muhasebe girdisi olarak düşünülmemesi, aynı zamanda toplumsal bir ilișki biçimi olduğunun göz ardı edilmemesi gerektiğini belirtir. Bu bağlamda aktif birey anlayışı çerçevesinde yaşlıların sosyal ilişkilerini geliştirmeleri, topluma katılım göstermeleri, yeni roller edinmeleri, kültürel ve sanatsal faaliyetlere katılmaları gibi mekanizmalarla yaşamlarını sürdürmeleri beklenmektedir. Yaşlılık devletin, politikaların ve tüm toplumsal kurumların sorumluluğunda olduğu gibi aynı zamanda bireylerin yaşam seyrinde öznel deneyimleriyle gelişen de bir süreçtir. Yaşlı bireylere yönelik olarak geliştirilen bu araştırma da, yaşlılık döneminde yaşlıların sosyal sermaye sahipliğinin onların yaşamlarına nasıl etki ettiğini ve neleri deneyimlediklerini konu edinmektedir. Bourdieu'nun sermaye kavramları arasında kültürel sermayenin her bir yașlı için öznel ve farklı olduğu gerçeğini dikkate alarak araștırmacılar, Coleman ve Putnam'ın sosyal sermayesi bağlamında yaşlıların sosyal ilişkilerinin nasıl olduğunun keșfine yoğunlaşmışlardır. Ancak araștırmada yașlı heterojenitesi önemsenmekle birlikte bu çalıșma doğrudan onların kültürel sermayelerinden kaynaklı sınıf yapısına odaklanmış değildir.

$\mathrm{Bu}$ kapsamda araștırmanın temel sorusu; yașlıların sahip olduğu sosyal sermaye düzeyi ile yalnızlık duymaları arasındaki ilișkilerin nasıl inșa edildiği, gündelik yaşamda kimlerle birlikte oldukları, neler deneyimledikleri, gönüllü kuruluşlarla ilişkileri ve kurdukları tüm ilişkilerdeki güven duygularının nasıl olduğudur. $\mathrm{Bu}$ bağlamda sahip oldukları sosyal sermaye düzeyinin yaşlıların yalnızlıklarını gidermede bir etki yaratıp yaratmadığ $\breve{l}_{\text {, yaratıoorsa }}$ nasıl bir etki yarattığı sorularına katılımcıların deneyimleri yoluyla araștırmada yanıt aranmıștır.

\section{ARAŞTIRMA YÖNTEMI}

Araştırmanın temel amacl, sosyal sermaye ve güven kuramı çerçevesinde yaşlı katılımcıların aile, akrabalık, arkadaşlık, komşuluk ilişkileri ve beklentileri ile topluma katılım (gönüllü-sivil topluluklara, sosyo-kültürel faaliyetlere katılım) deneyimlerinin nasıl ve neler olduğunun tespit edilmesidir. Böylece sosyal sermaye sahipliğinin yaşlıların yalnızlıklarını gidermede önemli bir faktör olduğu düşünülmektedir. Yaşlılık döneminde yaşlıların sosyal sermaye düzeyinin sık dokulu olmasının yalnızlık duymalarını azaltacağı yönündeki görüşten yola çıkılmıştır. Bu açıdan nitel bir araştırma üzerinden katılımcların öznel olarak deneyimlerine ilișkin anlamlandırmalarına önem verilmiș ve sosyopsikolojik bir yaklaşım çerçevesinde araştırma yürütülmüştür.

Araştırmamız sosyal sermaye, güven ve yalnızlık kuramları kapsamında katılımcıların deneyimlerine 
ve anlatılarına dayalı mikro ölçekli nitel bir araştırma olarak katılımcıların deneyimlerini ortaya koymak üzere tasarlanmıștır. Bu nedenle çalıșma neden-sonuç biçiminde ilișki arayıcı bir nicel araștırma modeli değildir. Katılımcılar, amaçlı ve kartopu tekniği ile belirlenmiş olup, Ankara'da Batıkent ve Bahçelievler bölgesinde ikamet eden 9'u kadın, 7'si erkek olmak üzere 65 yaş ve üzeri toplam 16 kişiden oluşmaktadır. Verilerin toplanması, yarı-yapılandırılmıș 34 soru ile derinlemesine görüşmeler yoluyla elde edilmiştir. Görüşmeler, 2020 Ocak-Nisan aylarında bizzat araştırmacılar tarafından gerçekleştirilmiş ve ifadeleri ses kayıt cihazına alınmıştır. Katılımcılarla yapılan görüşme süreleri ortalama olarak 50 dakika sürmüştür. Verilerin betimsel analizinde MAXQDA2 nitel analiz programı kullanılmıştır. Katılımcıların deneyim ifadeleri, analiz temaları altında verilirken benzerlik ve farklılık göstermesi kriter olarak alınmıștır. Görüșme yapılan katılımcıların isimleri kişisel verilerin korunması kapsamında K1, K2...şeklinde kodlanmış, metindeki ifadelerinin yanlarına ayrıca katılımcıların yașları ve cinsiyetleri belirtilmiştir.

\section{Sosyal Sermaye, Güven ve Yalnızlık Kuramları}

Sosyal sermaye teorisyenlerinin sosyal ilișkileri ele alışları, sınıflandırmaları ve kullanma amaçları birbirinden farklılıklar içermektedir. Avrupa "Aktif Yaşlanma İndeksi” (AAI)'nin (European Commission 2015:13), topluma katılım (participation in society) parametresi sosyal sermaye kapsamında değerlendirilebilir. Çünkü bunun açlımında yer alan ve topluma katılımı içeren 4 temel unsur sosyal ilişki ve sosyal sermaye ağlarının geliștirilmesiyle ilgilidir. Bunlar; yaşlıların çocukları ve torunlarına bakımı, yaşlıların yetişkin bireylere bakımı, yaşlıların gönüllü faaliyetlere katılımı ve yaşlıların politik katılım olarak siyasi karar mekanizmalarındaki yeri çerçevesinde siralanmaktadır. Bu sıralama Bourdieu, Coleman ve Putnam'ın görüşleriyle örtüşmekte ve sosyal sermayenin bileşkenini oluşturmaktadır.

Sosyal sermayenin ana fikri, bireyin sosyal ilişki ve iletişim ağlarının değerli bir servet olduğu konusundadır. Bourdieu (Allan, 2006:178-180), sosyal sermayeyi bireylerin sosyalizasyon sürecinde edindikleri sosyal ilişki ağları olarak kavramsallaștırmakta, habitusun olușumuna göndermede bulunmaktadır. Bourdieu sosyal sermayeyi, sosyal ilişkilerin miktarı ve gücü üzerinden tanımlamakta ve özellikle sosyal sermayeyi, üst sınıfa mensup ailelerin çocuklarının işe girmeleri açısından bir referans oluşturması yönüyle önemsemektedir (Field, 2008:10-19). Coleman ise sosyal sermayeyi toplumsal ilişkiler olarak görmekte, özellikle dezavantajlı kesimlerin firsatlardan yararlanmalarını sağladığına değinmektedir (Aydemir, 2011:45-47). Bu bağlamda Coleman'ın kuramı, yaşlıların sosyal ilișkilerinin ve bu ilișkilerden beklentilerinin değerlendirilmesini ve onların sosyal sermayeleri hakkında konuşabilmeyi sağlamaktadır. Robert

\footnotetext{
2 Bu araștırmanın nitel analizlerini yapma konusundaki katkılarından dolayı H.Ü. İ̈BF Sosyal Hizmet Bölümü Arş. Gör. Edip AYGÜLER'e ve Özlem AKYILDIRIM'a çok teşekkür ederiz.
}

Putnam'ın bireylerin iletişim ağları ve güven duygusunun toplumsal yaşama katılmanın bir yolu olduğunu belirtmesine referansla, yaşlı bireylerin sosyal sermayelerinin değerlendirilmesi onların toplumsal yaşamın fırsat ve olanaklarından ne ölçüde yararlandıklarını ve topluma politik olarak nasıl katıldıklarını göstermektedir (Field, 2008:60).

Sosyal sermayeyi inșa edilebilen kaynaklar bütünü olarak ele alan Coleman, bu kaynakların sosyal ağlar, aile yapısı, komşuluk ve arkadaşlık ilişkileri, yükümlülükler ve beklentiler olduğunu ileri sürmektedir (Coleman, 1988'den akt. Aydemir, 2011:47; Ekşi-Uğuz, 2010:33). Buradan yola çıkarak Coleman'ın sosyal sermayeyi aile ilişkileri ve sosyal ilişkiler olmak üzere iki boyutlu ele aldığı görülmektedir. Aile ve akrabalarla olan ilișkiler aile odaklı ilişkiler içerisinde sınıflandırılırken arkadaşlar, komșular ve kurumlarla olan ilișkiler sosyal ilișkiler olarak ele alınmaktadır. Öte yandan Coleman (Field, 2008:35), sosyal sermaye kavramını rasyonel seçim kuramı üzerine oturtmuștur. Buna göre bireyler yaşamlarında ve tercihlerinde rasyoneldir. $\mathrm{Bu}$ durumda bireyler eğer iş birliğini seçerlerse böyle davranmalarının nedeni onların çıkarlarına olduğu içindir. Böylece birey başkaları ile birlikte çıarı olduğu için yükümlülüklerini yerine getirir. Sosyal sermaye, aktörün grup ile olan bağını ifade eder. Dolayısıyla bireysel olan ile kolektif olan arasında köprü kurar. Örneğin bireysel olan aile ilișkileri ile toplumsal olan eğitim kurumu ya da ekonomi kurumu arasındaki ilişki gibi, aile ile ekonomi ya da eğitim ya da her iki kurumla birlikte bir köprü işlevi görür.

Sosyal ilișkilerin gücü ve niteliğinin sosyal sermayenin gücünü gösterdiğini belirten Bourdieu gibi Putnam da kolektif hayatın bir gereği olarak inşa edildiğini düşündüğü sosyal ilişkilerin yoğunluğu ve gücüne önem vermektedir (Aydemir, 2011:58). Putnam sosyal sermaye kavramını, yurttaşlık katılımını ve bu katılımdaki farklılıkları aydınlatmak için kullanmıștır. Böylece sosyal sermayeyi, güven, normlar, iletişim ağları gibi toplumun etkinliğini koordine eden eylemleri kolaylaștıran sosyal organizasyonların özelliklerine gönderme yaparak tanımlar (Field, 2008). Bu bağlamda araștırmamızda Avrupa Yașlanma Endeksinde (2014) yer alan gönüllü katılım ile politik katılım, Putnam tarafından yurttaşlık katılımı adı altında birlikte değerlendirilmiștir.

Yurttaşlık katılımı sivil örgütlenmeler olup aynı zamanda demokrasinin asli unsurlarıdır. Putnam toplumlarda sivil örgütlenmeleri önemsemiş ve bu örgütlerde çalışmayı hem bir yurttaşlık katılımı hem de demokrasinin bir gereği olarak değerlendirmiștir. Putnam'a göre birey için sosyal iletișim ağlarının bir değeri vardır. Sosyal ilişkiler/bağlar bireylerin ve grupların verimliliğini etkilemektedir. Putnam'da sosyal sermaye, bireyler arasındaki iletişim ağları ve buradan ortaya çlkan karşılıklılık ve güvenirlilik normları gibi bağlantıları ifade eder (Field, 2008:43).

Bununla birlikte Putnam sosyal sermayeyi, sosyal ağlara ve faaliyetlere katılım üzerinden değerlendirmektedir. Sosyal sermayeyi bağlayıcı ve köprü kurucu olarak ikiye ayıran Putnam, bağlayıcı sosyal sermayede grup içi dayanışmaya dikkat çekerek bu sosyal sermayedeki ilișkilerin daha sınırlı bir alanda ve içsel bağlardan oluştuğunu 
vurgulamaktadır. Köprü oluşturan sosyal sermaye ise, daha kapsamlı ilișkileri ele alan, farklı birlikteliklerin olduğu daha dışa açık bir topluluk yapısına işaret etmektedir. Tüm bu sosyal sermaye teorileri bağlamında katılımcıların aileleri, akrabaları, arkadaşları ve komşularıyla olan ilişkileri Putnam'ın bağlayıcı sosyal sermayesi çerçevesinde, kurumlarla olan ilişkileri ve gönüllü faaliyetlerde bulunmaları ise köprü oluşturucu sosyal sermaye çerçevesinde değerlendirilmektedir. Öte yandan sosyal ilişkilerde güven konusunun önemli olduğu ve güvenin sosyal sermayenin asli unsuru, göstergesi ve hatta ön koşulu sayıldığı ifade edilmektedir (Field, 2008; Cohen ve Prusak, 2001; Ekşi-Uğuz, 2010). Bu bağlamda sosyal ilişki ya da sermayenin bir güven ilişkisine ve değerler bütününe içkin olduğu anlaşılmaktadır.

Sosyal sermayenin genişliği ile yalnızlığın giderilmesi yönündeki açıklamalar yașlılıkta yașanan sorunlarla bir çeşit baş etme stratejisi olarak değerlendirilmektedir ${ }^{3}$. Yalnızlığın sosyal psikolojik bir kavram olduğuna değinen De Jong Gierveld ve diğerleri (2006) yalnızlığın, sosyal ilişki ağlarının zayıflığından kaynaklanan sıkıntı verici bir durumu imlediğini belirtirler. Bu durumda yalnızlık bireyin kendi tercihi olabileceği gibi, ilişki kurmakta zorlanma ya da kuramamaktan kaynaklanan yalnızlık da söz konusu olabilir. Her ikisi de bireyseldir. Literatürde yalnızlığın kișinin diğerlerinden uzak durması, kendisini meditasyon, tanrı gibi düșüncelerle var etmesi söz konusu olduğunda durumun olumlu yönünü, kişisel ilişkinin olmaması ya da çok zayıf olması, kendinin aranıp sorulmaması anlamında olumsuz yönünü ihtiva etmektedir. Wenger ve diğerlerine (1996) göre, arkadașlıkların bulunması ve güvenli ilişkilerin kurulması yalnızlığın panzehridir. Yalnız yaşayan yaşlıların genelde yalnızlık duygusuna kapıldıkları, yanlarında kimse olmadığı için acı hissettikleri ve yoksunlaștıkları görülür. Bazı durumlarda ise yalnızlığın bir öfke kaynağına dönüștügünü belirten Danıș (2005), bu durumda yalnızlığın sosyal ilişkilerde pasif ve isteksiz olmaya göndermede bulunduğunu da ekleyerek yaşlı bireylerin ekonomi ve sağlık durumlarının iyi olmamasından kaynaklanan nedenlerin, yalnızlığı tetikleyen faktörler olarak ele alınabileceğini belirtir.

$\mathrm{Bu}$ kuramsal açlklamalardan yola çlkarak araștırmamızda, özellikle Coleman ve Putnam'ın görüşlerinden oluşan aile içi ve aile dışı sosyal ilişkiler ile Putnam'ın grup içi ve grup dișı diyebileceğimiz sosyal sermaye görüşleri, güven ilişkisi üzerinden değerlendirilmekte ve yaşlı bireylerin yalnızlıklarını gidermede aile, akrabalık, komșuluk, arkadaşlık ilişkileri ile topluma katılım anlamında bağlayıcı ve köprü kurucu sosyal ilișkilerin rolünün nasıl olduğu keşfedilmektedir. Yalnızlık konusunda De Jong Gierveld'in, Wenger ve diğerlerinin görüşleri araştırmaya rehberlik etmektedir. Bourdieu'nun sosyal sermaye kavramı genel olarak üst sınıflara yaptığı atıflardan dolayı araştırmamıza dahil edilmemiş ancak kültürel sermaye kavramı

\footnotetext{
${ }^{3}$ Yaşlılıkta yalnızlık konusunda daha ayrıntılı bilgiye ulaşmak için Görgün-Baran, A. (2016). Yaşlllıkta sosyal izolasyon ve yalnızlık, Ed. H. Ceylan, Yaşlılık Sosyolojisi, İçinde İstanbul: Nobel Akademik Yayıncılık, s.77-97, yayınına bakınız.
}

çalışmamı açısından açıklayıcı olduğu için kullanılmıștır.

\section{BULGULAR}

$\mathrm{Bu}$ bölümde veri analizleri, sosyal sermaye ve yalnızlık kuramları ile katılımcıların deneyimledikleri pratikler bağlamında geliştirdiğimiz temalar eşliğinde mevcut literatür üzerinden tartıșlarak sunulmaktadır. Geliştirilen analiz birimi olan temalar 3 başlık altında toplanmıstır. Bunlardan ilki sosyal sermaye ve güven ilişkileridir. Bu tema 4 alt kategoriye ayrılmıştır. 1. Aile ilişkileri ve ailenin anlamı, 2. Akrabalarla ilişkiler 3.Arkadaş ve komşularla ilişkiler, 4. Arkadaş ve komşulardan beklentilerdir. İkinci analiz teması Politik katılım ve gönüllü-sivil kurulușlarla iliskkilerdir. Bu tema da kendi içinde Gönüllü kuruluşlara üyelik ve faaliyetlerine katılım ile Belediyelerle ilişkiler başlığı altında iki kategoride toplanmıștır. Üçüncüsü ise sosyal ve kültürel faaliyetlere katılım olarak belirlenmiștir. Katılımcların sosyo-demografik verileri temalardan bağımsız olarak ele alınmıștır. Şimdi sosyo-demografik verilerle katılımcılarımızı biraz yakından tanıyalım.

\section{Katılımcıların Sosyo-demografik Verileri}

Araștırma için Ankara'dan 65 ve üzeri yașta bulunan 16 katılımcıyla derinlemesine görüşmeler yapılmıștır. Görüşülen katılımcıların sosyo-demografik özelliklerine ilișkin veriler șöyledir;

Görüșme yapılan 16 katılımcının 9'u kadın, 7'si erkektir. Kadınların yaş ortalaması 75,2 iken erkeklerinki 75,86'dır. Katılımcıların eğitim durumu değerlendirildiğinde 4 kişinin üniversite ve yüksekokul, 2 kişinin lise ve 1 kişinin ortaokul, geriye kalan 7 kişinin ilkokul mezunu olduğu ve 2 kişinin de okuryazar olmadığı görülmektedir. Katılımcıların hepsi evlidir ancak 8'i eşlerini kaybettiklerini belirtmișlerdir. Araștırmaya katılan katılımclardan yalnızca 1'i çocuk sahibi değildir. 5 katılımcı 1'er çocuk, 3'er katılımcı sırasıyla 2'șer, 3'er ve 4'er çocuk, 1 katılımcı ise 5 çocuk sahibidir. Katılımcılardan 1'inin yetişkin çocuğu ile yaşadığı, 2'sinin ise kışın Ankara'da yazın ise memleketlerinde yaşadıkları görülmüștür. Diğer tüm katılımcılar Ankara'da eșleriyle birlikte ya da yalnız yașamaktadırlar. Görüşülen 16 katılımcıdan 4'ü kendilerinin ev kadını, 2'si emekli memur, 1'er kiși ise mühendis, tekniker, duvar ve ayakkabı ustası, çaycı ve sosyal hizmet uzmanı olduğunu, 4'ü ise hiç çalışmadıklarını belirtmișlerdir. Katılımcıların 14'ü emekli maașı ile ve bu katılımclardan 7'si kendi emekli maaşıyla geçinirken 6 kadın, 1 erkek katılımcı ise eşinden gelen emekli maaşı ile geçinmektedir. Katılımcılardan bir kısmı emekli maaşları dışında kira gelirleri, sahip oldukları gayrimenkul geliri ya da çocuklarının yardımı ile geçinmektedir. Katılımcılardan 1'i yaşlı aylığı aldığını ve 1 'i de gelirinin olmadığını belirtmiștir. Katılımcların ekonomik durumlarını nasıl algıladıkları sorulduğunda 5 kişinin ekonomik durumunu zayıf, yine 5 kişinin de iyi olarak değerlendirdiği görülmektedir. Katılımcılardan 6'sı ise ekonomik durumlarını orta olarak nitelendirmektedir. 
Tablo 1. Katılımcıların sosyo-demografik bulguları

\begin{tabular}{|c|c|c|c|c|c|c|c|c|c|c|c|c|c|c|c|c|}
\hline $\begin{array}{l}\text { Demograf } \\
\text { ik Durum }\end{array}$ & 1 & 2 & 3 & 4 & 5 & 6 & 7 & 8 & 9 & 10 & 11 & 12 & 13 & 14 & 15 & 16 \\
\hline Yaş & 74 & 77 & 75 & 67 & $70+$ & 70 & 70 & 87 & 66 & 89 & 77 & 78 & 84 & 75 & 65 & 84 \\
\hline Cinsiyet & Kadın & Kadın & Kadın & Kadın & Erkek & Kadın & Erkek & Erkek & Kadın & Kadın & Erkek & Erkek & Kadın & Kadın & Erkek & Erkek \\
\hline Memleket & Burdur & Tokat & Çorum & Çorum & $\begin{array}{c}\text { Amasy } \\
\text { a }\end{array}$ & Amasya & Sivas & Ankara & Ankara & $\begin{array}{c}\text { Giresu } \\
\mathrm{n}\end{array}$ & $\begin{array}{c}\text { Samsu } \\
\mathrm{n}\end{array}$ & $\begin{array}{c}\text { Çankı } \\
\text { rl }\end{array}$ & Ankara & Yozgat & Niğde & $\begin{array}{c}\text { İstanbu } \\
\text { l }\end{array}$ \\
\hline $\begin{array}{l}\text { En uzun } \\
\text { süre } \\
\text { yaşanilan } \\
\text { yer }\end{array}$ & Ankara & İzmit & Ankara & Ankara & $\begin{array}{l}\text { Merzif } \\
\text { on }\end{array}$ & Amasya & Ankara & Ankara & Ankara & $\begin{array}{c}\text { Ankar } \\
\mathrm{a}\end{array}$ & $\begin{array}{c}\text { Ankar } \\
\text { a }\end{array}$ & $\begin{array}{c}\text { Ankar } \\
\mathrm{a}\end{array}$ & $\begin{array}{c}\text { Malaty } \\
\text { a }\end{array}$ & $\begin{array}{c}\text { Ankar } \\
\mathrm{a}\end{array}$ & $\begin{array}{c}\text { Ankar } \\
\text { a }\end{array}$ & Ankara \\
\hline $\begin{array}{l}\text { Mezun } \\
\text { olunan } \\
\text { okul }\end{array}$ & $\begin{array}{c}\text { Ünivers } \\
\text { ite }\end{array}$ & Lise & İlkokul & İlkokul & $\begin{array}{c}\text { Ortaok } \\
\text { ul }\end{array}$ & İlkokul & $\begin{array}{c}\text { Üniversit } \\
\mathrm{e}\end{array}$ & $\begin{array}{c}\text { Yükseko } \\
\text { kul }\end{array}$ & $\begin{array}{l}\text { Kolej- } \\
\text { Lise }\end{array}$ & $\begin{array}{c}\text { İlkoku } \\
\text { l }\end{array}$ & $\begin{array}{c}\text { Hava } \\
\text { Harp } \\
\text { Okulu }\end{array}$ & $\begin{array}{l}\text { Okur- } \\
\text { yazar } \\
\text { değil }\end{array}$ & İlkokul & $\begin{array}{l}\text { Okur- } \\
\text { yazar } \\
\text { değil }\end{array}$ & İlkokul & İlkokul \\
\hline $\begin{array}{l}\text { Medeni } \\
\text { durum }\end{array}$ & $\begin{array}{c}\text { Eşi } \\
\text { ölmüș }\end{array}$ & $\begin{array}{c}\text { Eşi } \\
\text { Ölmüş }\end{array}$ & Evli & $\begin{array}{c}\text { Eşi } \\
\text { ölmüș }\end{array}$ & Evli & Evli & Evli & Evli & $\begin{array}{c}\text { Eşi } \\
\text { Ölmüș }\end{array}$ & $\begin{array}{c}\text { Eşi } \\
\text { Ölmüș }\end{array}$ & Evli & Evli & $\begin{array}{l}\text { Eşi } \\
\text { Ölmüș }\end{array}$ & $\begin{array}{c}\text { Eşi } \\
\text { Ölmüş }\end{array}$ & Evli & $\begin{array}{c}\text { Eşi } \\
\text { Ölmüş }\end{array}$ \\
\hline $\begin{array}{l}\text { Çocuk } \\
\text { sayısı }\end{array}$ & 2 & 3 & 4 & 4 & 1 & 1 & - & 2 & 1 & 3 & 2 & 5 & 4 & 3 & 1 & 1 \\
\hline Meslek & $\begin{array}{l}\text { Sosyal } \\
\text { hizmet } \\
\text { uzmanı } \\
\end{array}$ & $\begin{array}{c}\text { Ev } \\
\text { kadını }\end{array}$ & $\begin{array}{c}\text { Çalışmiy } \\
\text { or }\end{array}$ & $\begin{array}{l}\text { Çalışmıy } \\
\text { or }\end{array}$ & $\begin{array}{l}\text { Emekli } \\
\text { memur }\end{array}$ & $\begin{array}{c}\text { Çalışmıy } \\
\text { or }\end{array}$ & $\begin{array}{l}\text { Mühendi } \\
\mathrm{s}\end{array}$ & Tekniker & $\begin{array}{l}\text { Çalışmıy } \\
\text { or }\end{array}$ & $\begin{array}{c}\text { Ev } \\
\text { kadını }\end{array}$ & $\begin{array}{l}\text { Emekl } \\
\text { i albay }\end{array}$ & $\begin{array}{l}\text { Duvar } \\
\text { ustası }\end{array}$ & $\begin{array}{c}\text { Ev } \\
\text { kadını }\end{array}$ & $\begin{array}{c}\text { Ev } \\
\text { kadını }\end{array}$ & Çaycı & $\begin{array}{c}\text { Ayakka } \\
\text { bı } \\
\text { ustası } \\
\end{array}$ \\
\hline $\begin{array}{l}\text { Geçim } \\
\text { sağlama } \\
\text { yolu }\end{array}$ & $\begin{array}{c}\text { Emekli } \\
\text { maaşı }\end{array}$ & $\begin{array}{l}\text { Eşind } \\
\text { en } \\
\text { gelen } \\
\text { emekl } \\
\text { i } \\
\text { maaşı } \\
\text { ve } \\
\text { kira } \\
\text { geliri }\end{array}$ & $\begin{array}{c}\text { Eşinin } \\
\text { emekli } \\
\text { maaşı }\end{array}$ & $\begin{array}{c}\text { Emekli } \\
\text { maaşı ve } \\
\text { çocuklar } \\
\text { dan } \\
\text { gelen } \\
\text { yardım }\end{array}$ & $\begin{array}{c}\text { Emekli } \\
\text { maașı }\end{array}$ & $\begin{array}{c}\text { Eşinin } \\
\text { emekli } \\
\text { maaşı }\end{array}$ & $\begin{array}{c}\text { Emekli } \\
\text { maaşı ve } \\
\text { gayrimen } \\
\text { kul geliri }\end{array}$ & $\begin{array}{l}\text { Kendisin } \\
\text { in ve } \\
\text { eşinin } \\
\text { emekli } \\
\text { maaşı ve } \\
\text { birikimi }\end{array}$ & $\begin{array}{c}\text { Eşinin } \\
\text { emekli } \\
\text { maaşı ve } \\
\text { gayrimen } \\
\text { kul geliri }\end{array}$ & $\begin{array}{c}\text { Eşinin } \\
\text { emekl } \\
\text { i } \\
\text { maaşı }\end{array}$ & $\begin{array}{c}\text { Emekl } \\
\text { i } \\
\text { maaşı }\end{array}$ & $\begin{array}{c}\text { Yaşlı } \\
\text { ayllı̆̆ } \\
\text { ve } \\
\text { oğlu } \\
\text { bakly } \\
\text { or }\end{array}$ & $\begin{array}{c}\text { Eşinin } \\
\text { emekli } \\
\text { maaşı } \\
\text { ve } \\
\text { çocukl } \\
\text { arın } \\
\text { desteği }\end{array}$ & $\begin{array}{c}\text { Geliri } \\
\text { yok }\end{array}$ & $\begin{array}{l}\text { Emekli } \\
\text { aylığı } \\
\text { ve } \\
\text { çalışıy } \\
\text { or }\end{array}$ & $\begin{array}{c}\text { Emekli } \\
\text { maaşı } \\
\text { ve kızı } \\
\text { bakıyor }\end{array}$ \\
\hline $\begin{array}{l}\text { Ekonomi } \\
\mathbf{k} \text { durum } \\
\text { algisı }\end{array}$ & Orta & İyi & Orta & Zayıf & Orta & Orta & İyi & İyi & İyi & Orta & İyi & Zayıf & Zayıf & Zayıf & Zayıf & Orta \\
\hline
\end{tabular}


Katılımcıların meslek, eğitim, gelir, yaşam tarzı bakımından farklı sosyal sınıflardan olduğu anlașılmaktadır. Bu veriler araștırmada maksimum çeşitlilik sağlandığını göstermektedir. Görüşme yapılan kişilerin geçim kaynakları ile ekonomik durumlarına ilişkin algıları birlikte değerlendirildiğinde bu kişilerin eğitim durumları ya da meslekleri ile ekonomik durumlarını anlamlandırmaları arasında bir ilişki olduğu görülmektedir. Kendi anlamlandırmalarına ve ekonomik durumlarına bakıldığında katılımcıların orta-üst, orta ve alt sosyo-ekonomik düzeyde bulundukları söylenebilir. Şimdi araștırmanın analiz teması olan sosyal sermaye ve güven ilişkilerini görmeye çalışalım.

\section{Yaşlllıkta Sosyal Sermaye ve Güven İlişkilerinin Analizi}

Yașlılıkta sosyal sermaye ve güven ilișkilerini aile ilişkileri ve ailenin anlamı, akrabalarla ilişkiler, arkadaşlık ve komşuluk ilişkileri, arkadaş ve komșulardan beklentiler olarak dört bașlık altında sıralamak mümkündür. Sosyal sermayede önemli bir alan olan güven ilișkileri konusu ise ayrı bir kategori olarak değil, diğer temalar içine yedirilerek değerlendirilmiştir.

1.1. Aile ilişkileri ve ailenin anlamı "kızlarım benim hayatım"

Katılımclların aile kurumuna nası anlamlar yükledikleri dikkate alındığında, farklı tanımlamalar yaptıkları görülmektedir. Aile bireyleriyle olan ilişkiler üzerine bazı katılımcıların belirttikleri gibi fiziksel yakınlık ve uzaklık, ilişsilerin sürdürülebilirliği noktasında önem teşkil etmektedir. Katılımcıların ailenin anlamlandırılmasına yönelik ifadeleri de bu yakınlık-uzaklık ilişkisinden gelmektedir. Bu doğrultuda aile, sahip çıkılması gereken önemli bir kurum olarak nitelenmektedir. Özellikle bu konuda K4 (67, Kadın), K5 (70+, Erkek), K8 (87, Erkek), K10 (89, Kadın), K11 (77, Erkek) ve K13 (84, Kadın) kodlu katılımcların deneyimleri benzerlik taşıdığından aşağıda yalnızca K10'un (89, Kadın) ifadelerine yer verilmiştir.

"Aile bu yaşta benim elimde kalan son şey gibi. Memlekette çok kalabalık bir sülalem var, kız kardeșlerim var, onlar da yaşlandılar artık, uzaktalar. Ama kızlarım benim hayatım." (K10, 89, Kadın)

Ailenin anlamına yönelik olarak üstünde durulan ikinci bir tanımlama güvenmenin, güvenli ilișki kurmanın aile bireyleri için önemini göstermektedir. Katılımcılar aileye hayati bir önem vermekte, aileyi en büyük destek ve güven mekanizması olarak görmektedirler. Aile bir sosyal sermaye unsuru olarak içinde barındırdığı sosyal ilișkiler aracılığıyla hem bir toplumsal kontrol hem de meşrulaştırma sistemi olan güveni inşa etmektedir (Aydemir \& Tecim, 2012: 48). Geçmișten bu yana uzun bir süre birlikte oluşturulan ve paylaşılan bir yaşam söz konusu olduğu için aile üyelerinin birbirine güvenleri ileri yaşlarda daha pekişmiş olarak karşımıza çıkmaktadır.

Katılımcıların ailelerinden neler bekledikleri sorulduğunda; onlardan maddi bir beklenti içerisinde
"Aile ne demek, can ciğer demek kuzucum. Kimse olmaz yanında ailen olur. Sen en çok çocuklarına güvenebilirsin, onlar da sana." (K4, 67, Kadın)

"Biz eski insanlarız tabi ki aile önemli, 55 yıllık evli olarak çok sıkıntılar çektik ama bu sıkıntı bizi birbirimize daha çok yakınlaştırdı. Anladım ki aile en büyük liman, acı tatlı hatıralarla birbirimize destek vererek bu evliliği bugüne kadar getrdik. Şimdi sağlığımız el verdiği ölçüde çocuklar ve torunlarla safa sürme zamanı, çok şükür... Torunlar gelince yeniden doğmuş gibi oluyorum, săg olsunlar onlardan hiçbir saygısızlık görmedik, bizi çok sever sayarlar biz de onları çok severiz..." (K8, 87, Erkek)

Sosyal sermayeyi topluma güven duygusunun hâkim olması çerçevesinde tanımlayan Francis Fukuyama, güven duygusunun topluluk üyeleri arasında sosyal ilişkilerin kurulmasını kolaylaştırdığını vurgulamakta, Putnam da sosyal ilişkilerde güvenin işbirliğini kolaylaştırdığını belirtmektedir (Aydemir, 2011:6068). Aileye duyulan güven ve aileden görülen desteğin bağlılık ilişkilerinden geldiği görülmektedir. Birçok katılımcı aileden saygı ve sevgi ile birlikte güven içinde bir arada olmayı anladıklarını belirtmektedir.

"Duygu olarak beslendiğiniz kişilerdir onlar. Sizi onlar besler, siz de onlardan beslenirsiniz manevi olarak." (K1, 74, Kadın)

"Aile demek, bir arada olmak, birbirini mutlu etmek, ben öyle şey yapıyorum. Birbirine sahip çıkmak, saygı saymak..." (K3, 75, Kadın)

"Aile ne demek? Birbirine bağlılık, sevgi demek saygı demek. Bak șimdi kızım doğum yapacak, benim yeğenlerimin ikisi de gelecek. Íkisi de hemşire. Biz yani çok mutlu olduk. Birbirimizi tutarız, güveniriz işte böyle." (K6, 70, Kadın)

"Aile çok önemli, dertli oluyosun, sevinçli oluyosun iște bunları ev halkı ile beraber paylaşmak demek. Bașın sıkıştığında gidebileceğin, derdini anlatabileceğin bir yer. Eșim vefat etti evimde yalnızım. Kızımla aram iyi değil ama yine de benim evladım. Bir torunum var onunla çok iyiyiz, o bambașka bir sevgi....(duygulanıyor)."(K16, 84, Erkek)

Ailenin insan hayatının devamı olduğunu ve toplumun ve devletin çekirdeğini oluşturduğunu belirten K1 (74, Erkek) ve K3 (75, Kadın)'ün ifadeleri ailenin işlevselliğine vurgu yapmakta, toplumdaki değișim ile birlikte statükonun sürdürülmesi arasındaki çelişkiyi ortaya koymakta ve bu durum bir yönü ile modern, diğer yönü ile geleneksel kodların bir aradalığına vurgu yapmaktadır. Katılımcıların ifadelerinden anlaşılacağı üzere aile, karşılıklı olarak manevi ve sosyal ilișkiler anlamında üyelerini besleyen, doyuran bir birliktelik olușturmakta, bir nevi duygusal destek ve güven mekanizması olarak sığınılacak liman anlamında değerlendirilmektedir. Kızı ile arası iyi olmayan katılımcı (K16) bile her hâlükârda aile birliğinin önemine vurgu yapmaktadır.

olmadıkları, daha çok manevi destek olarak nitelendirebileceğimiz "sevgi ve saygı görmek", "aranıp sorulmak" gibi paylaşıma dayalı beklentiler 
içerisine girdikleri görülmektedir. Bu beklentiler katılımcıları mutlu etmekte ve onlara kendilerini değerli hissettirmektedir. Çocuk sahibi olmayan bir katılımcı (K7, 70, Erkek) aile ilișkilerinin önemine vurgu yaparken bir diğer katılımcı (K14, 75, Kadın) çocukları ve torunlarından gereken ilgiyi gördüğü için bir beklenti içinde olmadığını belirtmektedir.

"Benim çocuğum yok ama aileye ve aile ilişsilerine önem veririm, aile demek birlik demek, güven demek, sadakat demek. Tabi ki aynı zamanda sorumluluk demek. Bu şekilde dayanışmak, paylaşmak ve birbirimizi arayıp sormak, beklentim böyle bir şey". (K7, 70, Erkek)

“Ben kışın Ankara'da yazın Yozgat'da yaşıyom. Eşim ölmeden önce de böyleydi. O öldükten sonra oğlum daha bi benle alakadar olmaya başladı. Torunum da bana çok düşkün, hörmetkar. Yazın birlikte köye gediyoz, burda müstakil bir evimiz var biraz kallyolar sonra gidiyolar taa ki Ekim sonuna kadar. Burda kaynımgil, yeğenlerim, kız kardeșim var. Birlikte yiyoz, içiyoz, ekiyoz, biçiyoz, günler geçip gidiyo. Daha ne olsun bi beklentim yok, ihtiyaçlarımı karşılıyolar. Ben de kışlık erzak yapıyom. Ankara'ya giderken götürüyoz. (K14, 75, Kadın)

$\mathrm{Bu}$ iki katılımcının geleneksel değerler boyutunda bir deneyim inşa ettikleri anlaşılmaktadır. Çocukları ile ayrı yaşayanlar onların arayıp sormasından mutlu olurken belli dönemde birlikte olanlar ise zaten kalabalık bir aile içinde yaşadıkları için bu tür bir beklenti içinde olmadıklarını ifade etmektedirler. Aynı şekilde K12 (78, Erkek) de çocukları ve torunlarıyla bir sıkıntı yaşamadığını, kendisine yardımcı olduklarını, beklenti içinde olmadığını dile getirmiştir. $\mathrm{Bu}$ ifadeler şunu gösteriyor ki aile ile birlikte olmak yaşlı bireylere büyük bir doyum sağlamakta ve bir beklenti içinde olmadıklarına göndermede bulunmakta iken, ayrı yaşayanların dillerinden düşürmedikleri aranıp sorulmak isteği bir beklenti olarak sürekli vurgulanmaktadır. Her iki durumda da sosyal sermaye açısından geleneksel ilişkilerin varlığını ortaya koymaktadır.

Çocuklarıyla ve diğer aile bireyleriyle kurdukları ilișkilerde daha bağımsız olan katılımcıların çocuklardan ve torunlarından beklentilerinin daha az karşılıklılık ilişkisine dayandığı görülmektedir. Bu şekilde kentsel yaşamın ve çalışma hayatının getirdiği sorumluluklara vurgu yaparak sosyal ilişkilenme inşa eden bir katılımcı, beklentileriyle ilgili şunları dile getirmektedir:

“...benim yanımda olmaları gerekir diyemiyorum yani elbette yanimda olmaları beni mutlu eder ama onların da özel bir hayatı var, onların da iși gücü var. $O$ bakımdan öyle aşırı bir beklenti içinde değilim. Öyle "vah tüh n'olcak benim halim" gibi bi duygu yaşamıorum desem doğrudur." (K1, 74, Kadın)

$\mathrm{Bu}$ ifadeler Coleman'ın belirttiği rasyonel seçim kuramını hatırlatmakta ve yașlı bireylerin kendi yaşamlarını inşa etmede gerçekleri kabullenme ve ilişkilerini geliştirme üzerinden rasyonel davrandıklarını göstermektedir.

\subsection{Akrabalarla ilişkiler "iyi günde kötü günde birlikte} olmak"

Katılımclardan birinin yaptığı akraba tanımı, ihtiyaç anında bireylerin mesafeleri önemsemeden birbirlerine yardım etmeleri üzerine kurulmuştur. Bu tanım, akrabalık ilişkisinin ve yakın sosyal ilişkilerin dayanışma üzerine inşa edildiğini göstermektedir.

"Birimize bi șey olduğu zaman uzak da olsa yakın da olsa koșar gideriz, onlar da gelirler. Yani akraba durumumuz bizim için çok önemli. Akraba demek bambaşka bi şey." (K3, 75, Kadın)

Araştırmalar, samimi bir ortak bağ ile kurulan ilişkilerin bireyler üzerinde fiziksel, zihinsel, sosyal ve ekonomik anlamda bireyi sağlıklı kıldığını göstermektedir (Waite \& Gallagher, 2000'den akt. De Jong Gierveld \& Van Tilburg, 2006:488). Görüşme yapılan katılımcılardan bazıları akrabalarıyla olan ilişkilerini anlatırken bir süreklilik vurgusu yapmaktadırlar. $\mathrm{Bu}$ sürekliliğe iki farklı şekilde değinildiği görülmektedir. İlki, geleneksel bağların bireylerin kökenleri üzerinden okunması şeklindedir. Katılımcı bu sürekliliği şöyle dile getirmektedir:

"Zaten köy kökenli insanlarda biraz şeydir, geleneksel olarak böyle hani bi süreklilik vardır. Bayramda seyranda hani o hudutlar içinde, bir akrabalık zaviyesi içinde onlarla da temasım oluyor." (K1, 74, Kadın)

İkinci olarak vurgulanan süreklilik, çocukluk dönemlerinden getirilen bağların korunması şeklinde karşımıza çıkmaktadır. Burada yakın akrabalarla kurulan ilişkilerin düzenli bir şekilde devam ettirildiği görülmektedir.

Katılımcıların görüşmelerde en çok değindikleri konulardan biri akrabalarıyla olan fiziki uzaklığın sosyal ilişkiler ve bağlar üzerindeki etkisine yöneliktir. Katılımcıların bir kısmı fiziksel uzaklığın akrabalarıyla olan sosyal ilişkilerini etkilemediğini ve bu akrabalarıyla halen görüştüklerini belirtmişlerdir. Burada vurgulanan en önemli husus, uzaktakileri bir dokunuşla yakına getiren telefonun rolüdür. Katılımcılar, telefonun ilişkilerini devam ettirmedeki rolü hakkında şunları söylemektedirler:

"Akrabalarımın hepsi memlekette. Telefonla görüşüyoruz, gittiğimizde de görüşüyoruz, çok yakınız. Bir gün görüşmesek ikinci gün mutlaka görüsürüz telefonda." (K5, 70+, Erkek)

“...Her an için telefonla görüşüyoruz. Uzaktan ama birbirimizden haberdar oluyoruz. Birbirimizin her şeyine hemen koşuyoruz. Iyi günde kötü günde yalnız bırakmayız." (K6, 70, Kadın)

Uzaklık ile aile ve akrabalarla olan sosyal ilişkilerin telefon aracılığıyla sürdürülmesi ve telefonun bu anlamda olumlu bir etkisinin olmasının haricinde kimi katılımcılar uzaklığın sosyal etkileşimi azalttığını belirtmektedir. Bunun nedenini modern kent yaşamının hızlı ve zorlu yaşam koşullarına bağlamaktadırlar. 
“Cekirdek ailem dişındakiler arasında Ankara'da olanlar da var başka șehirlerde, yurt dişında olanlar da var. Uzaktakilerle ilişkiler ister istemez zayıfliyor." (K12, 78, Erkek)

"Akrabalarımla yıldan yıla bir görüşüyoruz. Coğunlukla telefonda görüşürüz. Herkes kendi halinde çoluğu çocuğu ile meşgul, ayrı şehirlerdeyiz. Ya ben giderim ya da onlar gelir birbirimizde yılda 15 gün kalırız. Bu tür bir ilişki yaşamak bana yetiyor mu derseniz, hayır derim ama şehir hayatının zorluğu geçim derdi insanları bu hale getiriyor.. " (K9, 66, Kadın)

Ankara'da ikamet etmekle birlikte köyleriyle bağını koparmayan katılımcılar aslında bu şekilde yaşamaktan memnun gözükmektedirler. Katılımcı K12 (78, Erkek) köyle şehir hayatı arasında sıkışmasına rağmen köydeki akrabaları ile ilişkilerinin iyi olduğunu, yazın köye kışın Ankara'ya oğlunun yanına geldiğini belirtmektedir. Bir katılımcı ise (K13, 84, Kadın), çok çocuk sahibi olduğu için Ankara, İstanbul ve Malatya arasında çocuklarının yanına gidip geldiğinden söz etmekte ve şunları söylemektedirler.

"Biz köylü insanlarız onun için akrabalarımız çok. Hepsi firsat buldukça gelip hatırımı sorarlar. Eee zaten köyde bir evimiz va kendimize göre bağımız bahçemiz va. Cocuklar burada olduğu için ekip dikme işlerini akrabalarım yapıyola, sağolsunlar, bizde yazın gidip 3-4 ay kalıyoz, köy havası bir başka her yer yeşillik. Toprak bizi sarj ediyo, Ankara'ya döndügümüzde kışı geçirecek güç kuvveti bulmuş oluyoz"(K12, 78, Erkek)

"Akrabalık ilişkileri bizde çok yoğun Ankara'dayım ama abimin, ablamın çocukları, burdaki köylülerimiz benim hatırımı her zaman sorarlar evden iç misafir eksik olmaz birlikte yapar birlikte yeriz. İyi ki varlar onlarla bir olunca hiç hastalığım aklıma gelmiyo, nasıl ki onlar gidilerse o zaman ăgrıyan yerlerim birden ağrımaya başlıyo, ne yapacan iște böle böle yaşayıp gidim" (K13, 84, Kadın).

Görüşme yapılan katılımcıların ailenin büyüğü konumunda olma ile ilgili iki hususa değindikleri görülmektedir. İlk olarak, aile büyüklerinin kayıplarıyla birlikte görüşme yapılan katılımcılardan biri ailenin büyükleri olarak onların yerlerini aldıklarını ve bu değișimden dolayı ilișkilerinin niteliğinin olumlu yönde değiștiğini vurgulamakta, ikinci olarak ise katılımcı bu durumun olumsuz sonuçlar doğurduğunu, kendisi açısından gidecek kimsesinin kalmadığını ifade etmektedir. Büyük olma olgusu, kendilerinden küçük olan bireyler tarafından daha çok aranmayl, hal ve hatırın sorulmasını getirirken, kendisinin gideceği büyüğünün kalmaması durumu ise katılımcıda burukluk yaratmaktadır. Katılımcılardan (K6,70, Kadın) ve (K8, 87, Erkek) bunu șu şekilde dile getirmektedir:

"Ailenin de büyüklerinden olduk șimdi. Onlar da yeğenlerim, kardeşimin çocukları, amcamın çocukları olsun ya da hanımın yeğenleri olsun hep arar sorarlar. Yani çok ilgilidirler." (K6, 70, Kadin)
"Akrabalara çok düşünüm ama zaten çok akraba kalmadı.. Çoğu hayatta değil. En büyükleri benim. Bayramda seyranda aile büyüğü olarak gelirler yanıma ama benim gideceğim büyüğüm kalmadı. (üzgün). Yeğenlerim var ayda bir dışarda yemekte buluşuyoruz. Telefonla konuşuyoruz, televizyon, sosyal medya bana yetiyor" (K8, 87, Erkek)

Weiss (1973)'in yaptığı sosyal ve duygusal yalnızlık tanımlarına referansla, görüşme yapılan bazı katılımcılardan özellikle aile bireylerini kaybedenlerin aile ve akrabalarından bekledikleri ilgiyi görmemeleri onların kendilerini sosyal olarak yalnız hissetmelerine neden olmaktadır çünkü, bu katılımcılar sosyal ilișki ağlarından bir kısmını kaybetmişlerdir. Ama katılımcı yalnızlığını telefon ve sosyal medya kullanarak Coleman'ın vurguladığı rasyonel seçimleriyle gidermeye çalışmaktadır.

Yapılan çalıșmalar, yaşlı bireylerin mutluluk kaynağı olarak temelde tüm aile bireylerini gördüklerini ancak çocuklarını, eşlerini ve torunlarını daha yakın hissettiklerini göstermektedir (Altay \& Avcl, 2009'dan akt. Karaağaç, Bayık Temel \& Yıldırım, 2019:38). Bu çalışmada ise aile ve akrabalık ilişkileriyle ilgili bazı katılımcıların çocuklarıyla ve torunlarıyla olan ilişkilerini, bazılarının ise kardeşleriyle olan iletişimlerini sıklıkla vurguladıklarına tanık olunmuştur.

Katılımcllar aile ve akraba bireyleri ile olan ilișkilerini uzaklık/yakınlık bağlamında değerlendirirken bunu fiziksel mesafe haricinde duygusal yakınlık ve bağlılık anlamında da değerlendirmektedirler. Bu durumda çekirdek aile vurgusu yapmakta, akrabalık ilişkilerini birinci ve ikinci derece yakınlık bağlamında değerlendirmektedirler. Birinci derece akrabalık ilişkisi içerisinde saydığımız çocuklar, katılımcılar tarafından da çoğunlukla değinilen sosyal ilişki aktörleri arasında yer almaktadır. Genellikle ikinci dereceden akrabalar arasında sayılan kardeşler, katılımcılar tarafından birinci derece akrabalar arasında görülmekte, yine ikinci derecede yer alan torunlar da katılımcılar tarafından çok vurgulanarak en yakın ilişkideki kişiler olarak yorumlanmaktadır. Katılımcların yakın çevrelerindeki bireylerle olan ilişkileri ve onlara hissettikleri yakınlıkları değerlendirildiğinde, özellikle çocuklarıyla olan olumlu ilișkilerini belirttikleri görülmektedir. Literatürdeki diğer çalışmalar da yaşlıların çoğunluğunun çocuklarıyla iyi geçindiğini belirtmektedir (ASPB, 2011'den akt. Özkul, Kalaycı \& Aslan, 2017:377-378).

"Valla Allah herkese benim evlatlarım gibi evlat versin..." (K3, 75, Kadın)

Katılımcıların çocuklarıyla olan ilișkilerinde de diğer yakınlarında olduğu gibi birtakım beklentilerin içine girdikleri görülmektedir. Çoğu katılımcı, çocuklarının kendilerine olan davranışlarını beğendiklerini, saygı ve sevgi gördüklerini belirtmekte, birtakım maddi ve manevi ihtiyaçlarının çocukları tarafından karşılandığını ya da onlar tarafından desteklendiklerini söyleyerek minnet duyduklarını ifade etmektedirler. Katılımcıların çocuklarıyla ilişkilerinde dikkat çekici olan șey, bu ilişkinin 
karşılıklı güvene dayalı olarak kurulmasıdır. Ebeveynlerini destekleyen çocuklar da aynı şekilde ebeveynleri tarafından desteklenmektedirler. $\mathrm{Bu}$ karşılıklılık hem Türkiye'de ebeveynlerin çocuklarının yaşları ne olursa olsun, onlarla ilgili sorumluluklarını yerine getirdiklerini göstermekte hem de anne ve babaların çocuklara yönelik bakış açılarını ya da çocuk algılarını özetlemektedir. McConatha ve arkadaşlarının (2004) yaptığı çalışmaya göre de çocukların ebeveynlerinin ihtiyaçlarını karşıladıkları geleneksel yapıya sahip ailelerde, ebeveynler ile çocukları arasında kültürden gelen bir bağ olduğu görülmektedir (McConatha \& ark., 2004'ten akt. Karaağaç \& Bayık Temel \& Yıldırım, 2019:38). Bu durum Bourdieu'nun habitus kavramını çağrıştırmakta ve kuşaklar arası dayanışma ilişkilerinin varlığına işaret etmektedir.

"Güzel, iki çocuğumuz oldu, çocuklarımdan memnunum. Sağlıkla ilgili sorunlarımızda hemen koşarlar, sıkıntılarımızı paylaşırız. Biz de onlara maddi manevi destek oluruz, onları da hep yanımızda görürüz. Kızlarım benim bütün beklentilerimi karşllyyorlar. $\mathrm{Bu}$ yașta rolleri değiștik ben onların çocuğu gibi oldum. Íkisi de gözümün içine bakarlar. Iyi baklyor bana kızlarım." (K11, 77, Erkek)

Katılımcıların çekirdek ailelerindeki ilişkilerle ilgili vurguladıkları diğer aktörler de eşleri ve torunlarıdır. Kimi katılımcılar eșleriyle yakın bir bağ geliștirmekte, eşlerinden duydukları hoșnutlukları dile getirmektedirler.

\section{“...ve herkese eșim gibi eș versin. Benim eșim bi tane." (K3, 75, Kadin)}

Aile içinde çocuklar ve torunlar haricinde önemli bir destek mekanizması olan eşlerin kaybı, literatüre bakıldığında yașlı bireylerin yalnızlık hissetmesinin temel belirleyicilerinden biri olarak görülmektedir (De Jong Gierveld, 1998:73). Böyle durumlarda özellikle yalnız yaşayan yaşlı bireyler için yetişkin çocuklar arkadaşlık, yakınlık ve paylaşım kaynağı olarak görülmektedir (De Jong Gierveld \& Van Tilburg, 2006:489). Bu araştırmada da görüşme yapılan katılımclardan 8'inin eşini kaybetmiş olduğu görülmekte ve katılımcılar için çocuklarının ilgisi önem teşkil etmektedir. $\mathrm{Bu}$ konuda yapılan araștırmalar da eșini kaybetmiș olan yașlı bireylerin yalnızlı hissinin çocuklarının ziyaretleriyle giderilebileceğini ancak tamamen ortadan kaldırılamayacağını göstermektedir (Hadley ve ark. 1975; Arling, 1980'den akt. Wenger, Davies, Shahtahmasebi \& Scott, 1996:336).

Katılımcılar torunlarıyla ilgili olarak, aynı çocuklarında olduğu gibi karşılıklı bir iletişim kurmaktadırlar. Torunları tarafından aranmayı, ilgilenilmeyi ve onlarla zaman geçirmeyi isteyen katılımcllar, torunları söz konusu olduğunda da onların olabildiğince yanlarında olmaya çalıştıklarını belirtmişlerdir. Buradan yetişkin çocukların ve torunların yaşlılar için sosyal destek mekanizması oldukları gibi, yaşlıların da torunlarına ve çocuklarına sağladıkları yardımlarla onlar için bir sosyal destek örneği oldukları görülmektedir. Aileler içerisindeki kriz anlarında yaşlı bireylerin torunlarına olan duygusal ve ekonomik desteklerinin sosyal gerilimleri çözmeye yardımcı olduğu düşünülmektedir (Görgün Baran, 2005'ten aktaran Özkul, Kalaycı \& Aslan, 2017:378). Yașlılardan yetișkinlere destek verme durumunu Avrupa Yaşlılık İndeksi (AAI, 2014) çerçevesinde topluma katılım açısından da yorumlamak mümkündür. $\mathrm{Bu}$ durum karşılıklılık esasında güven ilişkilerinin varlığına işaret etmektedir.

\section{“...Öyle bi denge görevim var aralarında. Benim sözümü dinlerler. Ama yoruldum da artık. Oğluma da diyom, bak oğlum ben denge terazisiyim, teraziyi tutuyom ama artık kolum yoruldu, gücüm yetmiyor diyom. Ama bu benim ailede mühim bi görevim." (K4, 67, Kadın)}

Çocuklarıyla ve torunlarıyla olan yakın ilişkilerin yaşlı bireylerin sosyalleşmelerindeki önemine değinen çalışmalar, yaşlıların bilgi ve deneyimlerini genç kuşaklara aktarmalarının aradaki duygusal bağı arttırdığını ve empati duygularını geliștirdiğini göstermektedir (Toseland, 2001'den akt. Karaağaç, Bayık Temel \& Yıldırım, 2019:37). Bu doğrultuda yașlı bireyler, ailelerin birlik ve beraberliğini sağlayan temel unsurlar olarak görülebilir.

"Valla ilişkilerimiz iyi, bi problemim yok. Ben elimden geldiğince torunlarımın yanında olmaya çalışıorum." (K4, 67, Kadın)

$\mathrm{Bu}$ veriler katılımcıların aynı zamanda güven ilișkilerinin varlığına ișaret etmektedir. Özellikle çocuklar ve torunlar katılımcıların en güvendikleri aile bireyleridir. Bu konuda bir katılımcı karșılıklılık ve paylaşmaya vurgu yaparak şunları söylemiştir:

“Güven konusu tabi ki ailem, kızım, torunlarım en güvendiğim kișiler, Bana göre artık güvenilecek kimse kalmadı, aileden basska.. Tabi herkes ailesine güvenecek demek değil, ben sanslıyım." (K9, 66, Kadın)

"Aileme, arkadașlarıma ve komșularıma güvenirim ama samimi, içten olmalarına dikkat ederim, sen iyiysen karşındaki de iyidir. Ĕger olumsuz bir durumunu görürsen ona karșı mesafe alırım." (K13, 84, Kadın)

Güven konusunda problem yașayan bir katılımcı ise konuyu şöyle anlatmıştır:

"Bi tek anama güveniyom bana diğer kardeșlerimden daha düșkün. Bașka da hiç kimseye güvenmiyom ne kardeşime ne arkadaşlara ne de başkasına. Ben bu çaycilıkta çok şey gördüm, çok şey ögrrendim. Hayat kötü. Isste iyi kötü bir ailen varsa ancak burada biraz rahat edebiliyon." (K15, 65, Erkek)

Aile, yaşlı bireyler için sosyal ve psikolojik destek mekanizmasının başında sığınılacak bir liman gibi algılanmaktadır. Yaşlıların sağlıklı ve uzun ömürlerinin olabilmesine yardımcl olan desteğin büyük bir kısmını ailesi sağlar. Bununla birlikte yapılan çalışmalarda yaşlı bireylerin, sosyal ve psikolojik destek mekanizması olarak en çok aile üyelerine güvendikleri görülmektedir (Fadıloğlu \& Özer 2006; Aksüllü \& Doğan 2004'ten akt. GöklerDanışman \& Aydın, 2011:70). Kaçan-Softa ve 
arkadaşlarının (2015:18) yaptıkları araştırmaya göre yaşlıların yaşam doyumunda akraba ve arkadaşlık ilişkilerinin etkili olduğu görülmüştür; akrabalarıyla görüşen yaşlıların yaşam doyumu puan ortalaması orta düzeyde bulunmuștur. Bunlar göz önünde bulundurulduğunda, yaşlı bireylerin aile üyeleri ve akrabaları ile ilgili güven algılarını anlamak, sahip oldukları sosyal destek açısından önem arz etmektedir.

\subsection{Arkadaş ve komşularla ilişkiler}

Türkiye gibi toplulukçu kültüre sahip ülkelerde yakın sosyal ilişkilere verilen değer özellikle yaşlı bireyler için daha da önem arz etmektedir. Yaşlanma dönemiyle birlikte geçmişteki bazı rollerini kaybeden, sağlık durumları değișen bireylerin sosyal çevrelerinde de bu anlamda bir değișiklik görülmektedir. Yapılan çalışmalar yaşlanma ile birlikte azalan sosyal çevreye dikkat çekerek bunun yaşlı bireyleri yalnızlığa itebildiğinden bahsetmektedirler (Altıparmak 2009; Ceyhan 2005; Erdil ve ark., 2000'den akt. Softa, Bayraktar \& Uğuz, 2016:2).

Aile ve yakın akrabalık ilişkileri her ne kadar yaşlı bireyler için en önemli güven ve sosyal destek mekanizması olarak görülseler de bireylerin bunların haricindeki yakın ve samimi ilișkileri onların topluma uyumunu, aidiyet duygusu geliștirmelerini ve bu yolla kendilerini daha az yalnız hissetmelerini sağlamaktadır. Yapılan araştırmalar da aile dışındaki yakın ilişkilerin önemli olduğunu hatta aile ilișkilerinden daha önemli olabileceğini göstermektedir (Abrahams, 1974; Bengston \& Kuypers, 1985'ten akt. Wenger, Davies, Shahtahmasebi \& Scott, 1996:335). Ailelerinden yeterli ilgi ve sevgiyi göremeyen yaşlı bireyler kendilerini aile üyeleriyle birlikteyken de yalnız hissedebilmekte, kendilerini daha rahat ve iyi hissedebilecekleri arkadaşlarına ya da komşularına yönelmektedirler. Literatürdeki kimi çalıșmalar da yalnızlığın eş veya çocuğun varlığı ile ilgisi bulunmadığını ancak arkadaşların varlığının önemli olduğunu belirterek bu görüşü desteklemektedirler (Mullins \& Mushel, 1992'den akt. Wenger, Davies, Shahtahmasebi \& Scott, 1996:337). Türkiye gibi birincil sosyal ilişkilerin önemli olduğu toplumlarda komșuluk ilișkilerine fazlaca önem verilmekte, komşular dayanışmanın temsilcisi olarak görülmektedirler. Dolayısıyla Putnam (2000)'ın tanımlaması çerçevesinde Türkiye'de bağlayıcı sosyal sermayenin yoğun olduğunu söylemek mümkündür (Aydemir \& Tecim, 2012:45).

Katılımcıların aile ve akrabaları gibi yakın ilișki ağları dışında arkadaşlık ve komşuluk ilişkilerini nasıl kurdukları ve devam ettirdiklerine yönelik olarak dikkat çeken ilk husus, bu ilişkilerin kurulmasında birkaç tane kriterin ön plana çıkmasıdır. Birlikte geçirilen sürenin uzunluğu, bireylerin birbirlerine yakın yaş aralıkları ve sosyal yakınlıklarını sağlayan fikir ve zevk birlikleri komșuluk ve arkadașlık ilişkilerini kurmada önemli hususlar olarak onların ortak kültürel sermayelerini oluşturmaktadır. $\mathrm{Bu}$ kriterler, bireyler arasında olușan güven duygusunun birlikte yașanan deneyimlere ve paylaşımlara bağlı olduğunu, dolayısıyla da yakın ilişkilerdeki bağların önemini ortaya koymaktadır.

\section{"28 senelik komşum hepsi. Fikirlerimiz, zevklerimiz uyuyor." (K2, 77, Kadın) \\ "Ankara'da yirmi yıldan fazla zamandır aynı apartmanda yaşıyoruz. Komşularımızın çoğu da bize yakın yaşta insanlar, aralarında çok yakın olduğumuz arkadaşlarımız da var.” (K11, 77, Erkek)}

Katılımclar arasında sosyal ilişkinin uzun ömürlü olması aynı zamanda kalıcılığının da göstergesi sayılmaktadır. Komşularla kurulan ilișkilerle ilgili birlikte geçirilen zaman vurgusunun, katılımcıların sosyal yakınlık kurmalarında bir faktör olmasının yanında eski komşuluklara duyulan özlem ile de birleștiği görülmektedir. Sosyal ilișkilerin zaman içerisinde geçirdiği dönüşüm birçok bakımdan geleneksel bağlarla kopuşu getirmekte, bu kopuş da hem aile gibi temel kurumsal birlikteliklerde hem de aile dışında daha kapsayıcı komşuluk ilişkileri, eğitim ilișkileri vb. gibi geniș ölçekte sosyal kurumlarda ve örgütsel ilişkilerde görünür olmaktadır (Aydemir, 2011:47; Kurtkapan, 2019:74). Dolayısıyla bireylerin yaşlılık dönemlerine kadar sahip oldukları sosyal ilișki ve çevreleri sosyal sermaye olarak onların yaşlanma dönemlerinde etkili olmakta, aktif yașlanma sürecini desteklemektedir. Katılımcılardan bazıları yeni komşuluk ilişkilerinden memnun olmadıklarını belirtmekte, eskiden kurdukları komșuluk ilișkilerini özlediklerini ve aradıklarını ifade etmektedirler.

"Komșularımla aram iyidir. Eskisi gibi gidip gelme yok ama hal-hatır sorarız. Danışacağım bir şey olursa gider sorarım, konuşurum. Komşularım iyidir. Herkesin kendine göre telaşesi var bu yüzden kimse kimseyi rahatsiz etmiyor. Ama eskiden bașkayd. Simdiki zaman başka o zaman başkaydı tabi" (K7, 70, Erkek)

"Birçoğunu tanımıyorum bile. Gelenler oluyor, taşınıp gidenler oluyor. Komşuluk hiç bizim gençliğimizdeki gibi değil artık." (K10, 89, Kadın)

Arkadaşlık ve komşuluk ilişkilerinde fikir, zevk ve beğeni tercihlerinin benzer olmasına dikkat ettiklerini belirten katılımcılardan bazılarının bu faktörün bireylerin sosyo-kültürel düzeylerine göre değiștiğini ifade ettikleri görülmektedir. Buradan yola çıkarak bazı katılımcıların sosyal ilişkilerinde seçici oldukları söylenebilir.

"Komşuluk ilişsileri pek yok gibi ilk başta gidip geliyosun sonra arkadan bir sürü laf eee... tabi ki küsüyosun, konușmuyosun. Bir müddet kiracı oldukları için habire taşınıyolar yerine yenileri geliyor ama șimdi kaç-göç devri olduğu için gidip gelme olmuyo. Zaten akrabalarımız bize yetiyo" (K15, 65, Erkek)

Katılımcıların çoğu komşularıyla olan ilişkilerinin olumlu olduğunu belirtmekte ancak istisnai olarak ilișkilerinin resmi olduğunu ya da bozulduğunu söyleyen katılımcılara da rastlanmaktadır. Bu durum, Aile ve Sosyal Politikalar Bakanlığı'nın 2011 yılında yaptığı araştırmanın verileriyle örtüşmektedir. Kimi 
yaşlı bireylerin önemli sosyal destek kaynaklarından biri olan komşu ve akrabalarıyla olan ilişkilerinde zayıflama, aile üyeleriyle olan ilişkilerinde ise güçlenme görülmektedir (Özkul, Kalaycı \& Aslan, 2017:378).

Katılımcıların sosyal ilișkileriyle ilgili olarak değinilmesi gereken bir diğer husus, arkadaşlık ve komşuluk ilişkilerinden bahsetmeleri istendiğinde neredeyse tamamının komşuluk ilişkilerinden söz etmeleridir. Bu vurgu, katılımclların birkaç tanesinin arkadaşlık ilişkilerine dair söyledikleriyle de örtüşmektedir. Görgün-Baran ve Kurnaz (2019:41) da yaşlı bireylerin aktif yaşlanma bağlamında sosyal ilişkilerini değerlendirdikleri çalışmalarında, yaşlıların sosyal çevreleriyle ilişkilerinde görülen en temel problemin sosyal ilişkilerdeki azalma olduğuna değinmekte, bunun bireylerin kendi yorumlamaları ya da çevrelerindeki ilginin azalmasına bağlı olarak ortaya çıktığına işaret etmektedirler. Araştırmamızda iki katılımcl, arkadaş ve güven kaybı karşısında deneyimledikleri pratikler nedeniyle ve yaşlarına bağlı olarak arkadaşlık ilișkilerinin azaldığı yönünde ifadelerde bulunmuşlardır.

"Çoğu emeklilik sonrası tatil beldelerine yerleştiler. Burada olanlar ise bir bir gidiyor, üzülüyorum ee tabi sıra bize de gelecek!" (K8, 87, Erkek)

Arkadaşım çok sınırl, hemen hemen yok gibi neden, çünkü insanlık yanlarından geçmemiş. Hepsi çıkar peşinde yazık...(K7, 70, Erkek)

Daha çok komşularıyla olan ilişkilerini anlatan katılımcılar, komşularıyla birlikte yaptıkları aktivitelerden de bahsederek günlük yaşamlarında sosyal ilișkilerini nasıl devam ettirdiklerine dair bir örnek de vermektedirler. Katılımcıların çoğunun kadın olduğu dikkate alınırsa komşularıyla daha çok çay sohbetleri ve günlerde bir araya geldiklerini ifade ettiklerini söyleyebiliriz.

"Biz herkesle iyiyiz. Ben herkese selam veririm, eşim de öyle. Ben dışarda selam verebiliyorum, sohbet edebiliyorum, hâl hatır sorabiliyorum. Yazın balkonda çay içmeye falan onlar geliyor, ben gidiyorum. Öyle idare ediyoz." (K5, 70+, Erkek)

"Burda kızımın yanında bir sitede yaşıyoz, kızım çalışıyo. Eee karşımdaki komşum çok iyi, emekli hep evde, eși ile birlikte kalıyo. Sabah akșam varlı vakitsiz birbirimize gidip geliriz. Bazen bana yemek yapar getirir. Bir șey olsa gelip bakar çok şükür, çok memnunum. Kattaki komşularım çok iyi işte onlarla vakit geçiriyoz" (K13, 84, Kadın)

$\mathrm{Bu}$ ifadelerden anlaşıldığı üzere toplumsal cinsiyet rollerinden kaynaklı olarak katılımcıların sosyal ilişkilerindeki aktiviteler de farklılık göstermektedir. Kadın katılımcılar çay ve kahve sohbetlerinden ve bunların sıklığından daha çok bahsetmektedirler. Toplumsal cinsiyet rolleri bağlamında bireylerin gündelik yaşam pratikleri değerlendirildiğinde kadınların ev işleriyle daha fazla vakit geçirdikleri, erkeklerin ise eşlerine "yardım" ettikleri görülmektedir. Bu durum, Korporaal, Van Tilburg ve
Van Groenou'nun (2008:308) belirttikleri gibi kadınların geleneksel olarak özel alanda ev ve aile odaklı sosyalleștiklerini gözler önüne sermektedir. Aynı durum daha önce değinildiği gibi katılımcılarımız arasında da gözlemlenmiştir.

\subsection{Arkadaş ve komşulardan beklentiler}

Görüşme yapılan katılımcıların arkadaş ve komşuluk ilişkilerinden beklentileri sorulmuş ve çoğunluğu komşularından beklentileri olmadığını belirtmişlerdir. $\mathrm{Bu}$ katılımcllar ailelerinden bekledikleri gibi arkadaş ve komşularından da sıklıkla sevgi ve ilgi beklemekte ve bu ilgiyi de birbirleriyle vakit geçirme olarak talep etmektedirler.
"Komşularımdan, arkadaşlarımdan bir beklentim yok. Komşularım aynı zamanda arkadaşlarım sayılır. Birbirimize saygıll, güler yüzlü olalım yeter. Ama bilirim ki kimin kapısını çalsam benim yardımıma koşar, bu duygu insanı rahatlatıyor." (K9, 66, Kadın)
"Biz istiyoruz ki komşularımız bize gelsin oturalım, memleketimizde de öyle alıștık. Biz onlara gidelim. Ailecek görüsmelerimiz olsun, vakit geçsin. Arayıp sorabilelim." (K5, 70+, Erkek)
Arkadaşlarımızla, komşularımızla sohbet etmek, eski yaşanmışlıkları anlatmak hoșça vakit geçirmekten başka ne isteyebiliriz ki. Hepimizin zamanı el verdikçe arkadaşlarımla bunları yapmaya çalışıyoruz. Ne de olsa eski dostlar deniliyor ya bizimkisi öyle bir şey" (K8, 87, Erkek)

Katılımcı kadınların birçoğu komşuları ile arkadaşlarının aynı kişiler olduğunu belirtmişlerdir. Erkeklerin ise kamusal alanla olan bağları nedeniyle mesleki arkadaşlıklarını devam ettirdikleri anlaşılmaktadır. Katılımcılar komşularıyla olan ilişskilerini dayanışma üzerinden tanımlamakta, zor zamanlarda birbirlerinin yanlarında bulunduklarını ifade etmekte ve bu durum onların karşılıklı olarak güven bağlarını göstermektedir. Birbirleriyle ilgilenmeleri, ihtiyaç duyduklarında birbirlerinin yanında bulunmaları, telefonla da olsa hal ve hatır sormaları ve sevgi görmelerini sosyal destek aracı olarak gören katılımcıların bunları aynı zamanda arkadaş ve komşularından da bekledikleri görülmektedir. Bu ilgi ve sevgi beklentisi önemli bir duruma işaret etmektedir. Sevgi ihtiyacının anlaşılmış hissetme arzusundan geldiğini belirten C.H. Solano, sevilme ihtiyacının en temel insani ihtiyaçlardan biri olduğunu belirtmektedir (Solano, 1986:235). Dolayısıyla katılımcıların aradıkları şey, sevgi ve güvene dayalı karşılıklı dayanışma ilişkilerinin sürdürülmesidir.

\section{"Herhangi bir șey olduğu zaman hepimiz birbirimize koşabiliyoruz. Bi derdimiz olduğu zaman gidebiliyoruz." (K3, 75, Kadın)}

Bununla birlikte bazı katılımcılar çocuklarından ve yakın akrabalarından olduğu gibi komşularından da maddi ve manevi hiçbir beklentileri olmadığını ifade etmektedirler. Beklentisizlik, bu katılımcların insanlarla olan ilişkilerinde daha resmi olduklarını, 
inançla birleşen kendine yetme isteğini ya da yaşadıkları kötü tecrübelerden dolayı güvenlerinin zedelenmesiyle ortaya çlkan umutsuzluk içinde olduklarını düşündürtmektedir.

"Valla kimseden bir ssey bekliycek durumda değiliz yavrum, herkes için konuşuyorum. Kimse kimseden artık bi şey beklemiyor." (K3, 75, Kadın)

"Kimseden bi beklentim yok. Kimseye muhtaç olmayım yeter. Merhaba merhaba." (K4, 67, Kadın)

Katılımcların en çok bahsettikleri beklentilerden biri kendilerini güvende hissetmelerini sağlayan sosyal dayanışma içinde olmalarıdır. Katılımcılar zor durumda kaldıklarında ya da ihtiyaç anlarında birbirlerinin yardımına gereksinim duyduklarını belirtmekte, birbirlerini güvence olarak görmektedirler. Katılımcılardan biri komşuluğun önemini bunun üzerinden okumakta, ihtiyaç anında duyulan en büyük destek olarak komşuluğu görmektedir.

"Komşu yeri geliyor bize aileden daha yakın oluyor. En acil sıkıntılarda başvurulabilecek bir kapı oluyor." (K10, 89, Kadın)

"3 tane komşum var burda, çok iyiler. Nasıl söyleyim eksik olmasınlar. Hepsinde anahtarım var. Gece falan kapım açılmazsa beni kontrol edin diyorum." (K2, 77, Kadın)

Komşulara duyulan güven duygusu, hem bireylerin paylaşımlarına bağlı olarak ilişkilerin sürdürülmesine bağlı olmakta hem de katılımcıların komşularıyla olan ilişkilerini güçlendirmektedir. Putnam, toplumsal güvenin temelinin bireyler arasındaki iș birliğinin başkalarına güvenmekten ve başkaları tarafından da güvenilir olarak algllanmaktan geçtiğini belirtmektedir (Putnam, 1993'ten akt. Aydemir, 2011:60).

\section{Politik Katılım ve Gönüllü-Sivil Kuruluşlarla İlişkiler}

$\mathrm{Bu}$ ikinci temada gönüllü kuruluşlara üyelik ve faaliyetlerine katılım ile belediyeler ile ilişkiler başlığı altında iki alt kategori geliştirilmiştir. Coleman'ın görüşüyle sosyal ilişkiler merkezli sosyal sermaye biçimi içerisinde ele aldığımız kurumlarla ilișkiler, yaşlı bireyler için sosyalleşmenin başka bir kaynağı olarak karşımıza çıkmaktadır. Van Tilburg ve De Jong Gierveld (2006:489-490) de bireylerin gönüllü çalışmalar içerisinde bulunmasının onları bir araya getirdiğini ve yalnızlık duygularını azalttı̆̆ını ifade etmektedir. Bireylerin kurumlarla kurdukları ilişkiler onları birey merkezli sosyal ilişkiler ağından kurumlar merkezli bir sosyal iletişim ağına geçirmektedir (Aydemir, 2011:47). Bu konuda, sosyal ilișki ağlarının genişliğinin yaşlanmanın, kırılganlığın giderilmesi üzerinde olumlu etkisinin olduğu belirtilmektedir (Görgün Baran, 2008:93). Bireylerin rol ve statü kayıpları karşısında Coleman'ın deyișiyle aile ilişkileri ile aile dışı sosyal ilişkilerinin bir denge unsuru oluşturması bağlayıcı ilişkiler geliştirmek bakımından değerlendirilebilir. Dolayısıyla çalışmanın bu kısmında gönüllü ve sivil topluluklarla ve belediyelerle olan ilişkiler değerlendirilmektedir.

\subsection{Gönüllü kuruluşlara üyelik ve faaliyetlere katılım}

Bu bașlık Avrupa Aktif Yaşlanma kriterinin politik katılım konusuna girmektedir. Türkiye'de yaşlı bireylerin gönüllü kuruluşlarla olan ilişkilerinin sınırlı olduğu bilinmektedir (Görgün-Baran ve diğerleri, 2005). Yapılan çalıșmalarda, mesleki hayatlarından emekli olan bireyler rol ve statü kayıpları neticesinde yaşamdan geri çekilme durumunu yaşamaktadırlar. Geri çekilme ve aktivite teorileri bağlamında sosyal ilişkileri değerlendirilen yaşlıların meslek hayatlarından ve sosyo-kültürel çevrelerinden uzaklaştıklarında yalnızlaştıkları yönünde genel bir yargl bulunmaktadır (Kurt, Beyaztaş \& Erkol, 2010'dan akt. Karaağaç, Bayık Temel \& Yıldırım, 2019:38). Meslek hayatlarından ayrılan katılımcıların rol ve statülerinde belli değişiklerin olması mümkün olmakla birlikte her bir yaşlı birey için böyle bir genelleme yapmak uygun değildir. Emeklilikten sonra çalışmaya devam eden yaşlılar olduğu kadar profesyonel anlamdaki bilgi ve deneyimlerini ya da yetenek ve ilgilerini başka alanlarda kullanan bireyler de bulunmaktadır. Bu bireyler yeniden işgücüne katılarak, yardım ve dini inançlarıyla ilgili topluluklarda veya gönüllü olarak derneklerde yer alarak toplumla daha fazla bütünleşme (De John Gierveld \& Van Tilburg, 1998:74) firsatı yakalayabilmektedir.

Putnam, köprü oluşturan sosyal sermaye biçiminde kolektif eylem ve karșilıklılık ilkelerine değinmektedir. Bu ilkelerin toplumsal ilişkilerin ortak faydaya dönüştürülmesi noktasında önemli olduğunu belirtmektedir (Aydemir, 2011:56). Bu sermaye çeşidi, belli ortak amaçlar için bir araya gelen bireylerin kolektif bir şekilde harekete geçmek için sahip olduğu sosyal ilişkileri göstermektedir. Köprü oluşturan sosyal sermaye, çeşitli sosyal bölümler içinden insanları bir araya getirme olanağı vermektedir (Field, 2008:62). Dolayısıyla gönüllü faaliyetlerde herhangi bir kurum veya kuruluş içerisinde bulunmak yaşlı bireylerin farklı sosyal ilişsiler içerisinde bulunmasını ve bașkalarıyla ortak bir amaç için birlikte hareket etmesini sağlayarak onlar için başka bir sosyal destek aracı olmaktadır.

Kendilerine üye ya da gönüllü olarak herhangi bir sivil topluluğun içinde yer alıp almadıklarına dair soru yöneltildiğinde, katılımcıların yalnızca iki tanesi aktif katılım gösterdiklerini belirtmişlerdir. Katılımcılardan biri gönüllü olarak sosyal hizmet alanında faal olduğunu belirtirken diğeri yardımlașma dernekleri, meslek örgütü ve sosyal gruplar olmak üzere farklı sivil toplum kuruluşlarına üye olduğunu, bir başka katılımcı ise aktif katılım göstermemekle birlikte yardım kuruluşlarına maddi olarak destek verdiğini ifade etmektedir. Görgün-Baran ve Kurnaz, (2019:43), sosyal sermayenin orta yetişkinlik ve ilerlemiş yașta olma ile gönüllülük yapma arasında eğitim değişkeni göz önünde bulundurulduğunda doğrudan bir ilişki olduğunu belirtmektedirler. Bu araştırmada da aktif olarak topluluklara katılım sağlayan iki katılımcının eğitim düzeyinin üniversite olması ve bu kişilerin emeklilikten önce profesyonel mesleklerde çalışmaları Görgün-Baran ve Kurnaz'ın (2019) tespitleriyle uyuşmaktadır. Katılımcıların aktif katılımı, yaşlılık dönemini de boş kalmadan aktif bir 
şekilde geçirmelerini ve işe yarama duygusunu hissetmelerini sağlamaktadır.

"Dış Türklerle ilgili kişilere yardımcı olmaya çalışıyorum. Yani o alanda çalışıyorum. Napsam bugün diye çok da canımın sıkıldı̆̆ını söyleyemicem. Canımın sıkılmasına meydan vermiyorum desem olur." (K1, 74, Kadın)

Ben mesleki bir kuruluşun üyesiyim. Ayrıca bizim hemșeri derneğimiz var onların yaptıkları tüm faaliyetlere katıliyorum. Bazen gezileri oluyor eşimle birlikte gidiyoruz. (K8, 87, Erkek)

Katılımcıların çoğu kurumların sağladığı imkânlardan yararlanamadıkları gibi yine torun ve yașlı bakımı, evlat desteği, ev içi işler nedeniyle vakitlerini gönüllü faaliyetler içerisinde yer almaya ayıramadıklarından bahsetmektedirler. Yapılan araștırmalar sonucunda özellikle yaşlı kadınların torun bakımı, evin işlerinin yapılması ve aile içi iletişimin sağlanması gibi sorumlulukları taşıdıkları ve boş zamanlarında da TV izlemek, ibadet etmek ya da komşuları ziyaret etmek gibi ev içi alandaki faaliyetleri yaptıkları görülmektedir (Arun, 2008'den aktaran Özkul, Kalaycı \& Aslan, 2017:381).

"Yapacak durumum da vaktim de yok. Vaktim de olsa artık istemem çünkü koşucak halim yok bu yaștan sonra tamam. Çocuklarımı büyüteyim, șu torunları, bütün isteğim arzum onlar." (K3, 75, Kadin)

“Öyle șeylere vaktim yok. Bir sürü işim var zaten evde." (K6, 70, Kadın)

Geçmişte derneklerde, kooperatif ya da okul aile birliklerinde gönüllülük yapan katılımcılar şu anda gerek değişen yaşam koşullarından gerekse de sağlık koşullarından dolayı gönüllü olarak herhangi bir kuruluşun içinde bulunmadıklarını ya da gönüllülük yapmadıklarını belirtmektedirler. Katılımcılardan bir tanesi hayatı boyunca hiç gönüllü bir faaliyette bulunmadığını belirterek yaşlandıkça neden katılım göstermediğini sorguladığını belirtmektedir.

"İste eskiden memleketin derneği vardı da 20 yıl evvel biraktım daha da gitmedim. Orda her șeye koștururdum. Halim de vardı. Simdi öyle değil. Simdi hiç alakam yok bu işlerle. Gidemem $\mathrm{ki}$ zaten, gitsem de yetişemem bir şeye." (K4, 67, Kadın)

“Çocuklarım küçükken okul aile birliklerinde yer alırdım. Farklı şeyler yapardık. Cok uzun yıllardır hiçbir toplulukta yer almadım." (K10, 89, Kadın)

Gönüllü faaliyetlerin yaşlı bireyler üzerinde hem fiziksel hem de duygusal olarak olumlu etkileri olduğu bilinmektedir. Araştırmada, gerek ev içi sorumluluklar ve sağlık durumlarında yaşadıkları problemler gerekse de ilgi ve motivasyon eksikliğinden dolayı görüşme yapılan katılımcıların çoğunun gönüllü kuruluşlara üye olmadıkları gibi, gönüllü faaliyetlerde de bulunmadıkları ya da katılım düzeylerinin düşük olduğu görülmektedir. Bu durum, görüşme yapılan yaşlıların toplumsal alana katılımları bağlamında aktif olmadıklarını ve katılımcıların alternatif sosyalleşme alanlarının bulunmadığını göstermektedir. $\mathrm{Bu}$ katılımcıların aile ve komşuluk ilişkilerinin güçlü olması yaşamlarında belli bir doyumu getirdiği için kuruluşların faaliyetlerine katılmaya istek duymadıkları yönünde bir yorum yapılabilir. Kurum ve kuruluşlarda gönüllü olarak yer alan bireylerin ise daha fazla aktif yaşam içerisinde bulundukları, dernekler sayesinde kendilerine alternatif bir sosyalleşme alanı yarattıkları söylenebilir.

\subsection{Belediyeler ile ilişkiler}

Katılımcılar politik katılım konusunda seçimlerde vatandaşlık görevlerini yerine getirdiklerini, oy kullanmanın dışında bir etkinliklerinin bulunmadığını belirtmişlerdir.

Belediyelerin, halk eğitim merkezlerinin ya da özel yaşam merkezlerinin kendilerine tanıdığı imkanlardan haberdar olup olmadı ̆̆ sorulduğunda, katılımcıların bazıları haberdar olmadıklarını ve hatta ilgilenmediklerini belirtmekte, bir kısmı başkaları aracılığıyla haberdar olduklarını ancak vakit ayıramadıklarını, bir kısmı ise belediyenin yaşlı hizmetlerinden yararlandıklarını ifade etmişlerdir.

\section{"Hayır, haberdar değilim. İhtiyaç duymadığımı hissediyorum." (K3,75, Kadın) \\ "Kızım dolayısıyla biliyorum bazılarını. KIzım hatta katıllyor da bazı kurslara. Ben hiç faydalanmadım." (K10, 89, Kadın)}

Görüşme yapılan katılımcıların büyük bir kısmı kurumların sağladığı imkanlardan haberdar olduklarında dahi torun bakımı ve yaşlı bakımı, ev içi sorumluluklardan dolayı etkinliklere vakit ayıramadıklarını belirtmektedirler. Böylece Avrupa Aktif Yaşlanma kriterleri kapsamında yaşlıların çocuk ve torun bakımını üstlenmelerini de aktif yaşlılık içerisinde değerlendirdikleri bilindiği için bu katılımcıların her ne kadar politik katılım açısından belediye gibi yerel kuruluşların faaliyetlerine katılmasalar bile aktif oldukları söylenebilir.

"Haberdar oluyorum da zamanım olmuyor benim. EV isleri bu kadar olmasa giderdim. Cok severim öyle şeyleri ama zamanım yok." (K6, 70, Kadın)

"SSu anda hiçbir yere kıpırdayamıyorum bu torunun yüzünden ama tabii daha evvelden onları takip ediyordum mesela. Simdi katıldığımız kurslar falan yok, onlara vaktimiz yok. Hepsinden eli ayă̆ı çektik." (K5, 70+, Erkek)

Genel olarak K15, (65, Erkek), K11, (77, Erkek), K4 (67, Kadın) başta olmak üzere, katılımcıların yarısından fazlasının kurumların imkanlarından haberdar oldukları ama aktif olarak halihazırda bu imkanlardan yararlanmadıkları tespit edilmiștir. Bazı katılımcılar yaşlılık dönemlerinden önce de kendilerinden beklenen sorumlulukları yerine getirirken kendi sosyal ve kültürel ihtiyaçlarına vakit ayıramadıklarını, yaşlılık döneminde ise bunları yapacak fiziksel güce sahip olmadıklarını düşündüklerini belirtmektedirler.

"Ingilizce kursları, çiçek, moda, dikiş, el sanatları...hepsinden haberim var ama zamanım 
yok hiç onlara gidemedim. Torun büyüttüm, anneme baktım. Kendime ayıracak zamanım, özel yaşantım olmadı. Şimdi var ama artık sabah erken kalkıp gitme gibi bir performansım yok." (K2, 77, Kadın)

"Haberim var ama gitmiyom. Yakında olsalar da gitmezdim. Hem sağllk sorunlarım var hem de panik atak yüzünden toplum içine çıkmak istemiyorum. Sikıntı geliyor bana darlanıyom." (K4, 67, Kadın)

Ev içi sorumlulukların, torun ve yaşlı bakım hizmetinin ve yaşlılıkla birlikte fiziksel olarak yaşanan problemlerden dolayı kendilerine sunulan hizmetlerden yararlanamadıklarını söyleyen katılımcılarla birlikte, yaşlı bir birey olmanın getirdiği kazanımlardan yararlandığını belirten katılımcılar da vardır. $\mathrm{Bu}$ katılımcılar, belediyelerin kendilerine sunduğu ulaşım ve sosyal hizmetlerinden yararlanmalarını memnuniyetle anlatmaktadırlar.

"Evet biz belediye hizmetlerinden yararlanıyoruz, otobüs, metro ücretsiz, kullanıyorum. Evin temizlik işleri için belediyenin yaşlı hizmetlerine telefon ediyorum, gelip evi 15 günde bir temizliyorlar, memnunuz." (K8, 87, Erkek)

Kurumların imkanlarından çoğunlukla haberdar olan ancak aktif olarak katılım göstermeyen katılımcılar, her ne kadar imkanlardan yararlanmasalar da kurumların sağladığı imkanları büyük oranda yetersiz bulduklarını belirtmektedirler. Görüşme yapılan katılımcıların yaș aralıkları göz önünde bulundurulduğunda (65+), bu yaş grubundaki bireylerin ihtiyaç ve beklentilerini karşılayan imkanların halen yeterli olmadığı görülmektedir. Katılımcıların sıklıkla değindikleri ilk konu, kurumlara ulașım sıkıntısı ya da sağlanan olanakların yașlıların erișimine uygun olmadığı yönündedir.

"Buranin belediyeleri uzak. Gidemiyorsun, gelemiyorsun." (K5, 70+, Erkek)

"Var ama benim alakam yok. Yok da öyle bir şeyler yani hiç gitmemişimdir. Bu çay bahçesi belediyenin. Burası arsayd, sonradan iște Allah'tan yaptılar da park yaptılar da geliyoruz, baya güzel oldu" (K16, 84, Erkek)

Katılımcıların vurguladıkları ikinci konu, özellikle halk eğitim merkezleri ya da belediyelerin kurs ve etkinliklerinin çeşitliliğine yöneliktir. Katılımcıların sosyal ve kültürel faaliyetlerin çeșitliliğini bekledikleri görülmektedir. $\mathrm{Bu}$ durum, görüşme yapılan katılımcıların vakit ayıramama dıșında kendilerine hitap eden bir etkinliği bulamamaktan kaynaklı olarak da katılım sağlayamadıkları yönünde bir argümanı akla getirmekte ya da gerçekten ilgilenmedikleri için haberdar olmadıklarını düşünmemize yol açmaktadır. Oysa Büyükşehir Belediyesinin yaşam merkezlerinde İngilizce kursu, bilgisayar kullanma, folklor ve çeşitli sanat kursları bulunmaktadır. Bu konuda olumsuz görüșe sahip (K2, 77, Kadın) ile olumlu görüșe sahip (K7, 70, Erkek) kurslar hakkında şunları söylemiștir:

"Valla yeterli değil. Daha daha güzel, özellikle lisan bakımından, yabancı dil bakımından daha çok olsa, dil kursu var ama yetersiz, her mahallede olsa... Belediyelerin imkânı, her yönüylen, el sanatları olsun, kültürden olsun, tiyatro olsun hepsi olsun, bunlar iyi" (K2, 77, Kadın)

Aslında Büyükşehir Belediyesinin çok güzel ögretici kursları var, ben bilgisayar kursuna katılmıştım. Üniversiteden bir hoca geliyordu. Bize çok iyi ögretti. Kimin neye ihtiyacı varsa ona yönelik kursalar var belki yeterli değil ama takip etmek gerekli, üstelik ücretsiz.(K7,70, Erkek)

Bu farklı görüşler, katılımcıların ilgi ve meraklarıyla ilgili olduğu kadar kursların herkesi kapsayıcı şekilde olmadığına dikkat çektikleri yönünde yorumlanabilir.

3. Sosyal ve Kültürel Faaliyetlere Katılım (Keyif Alınan Aktiviteler)

Araştırma analizinin üçüncü teması sosyal ve kültürel faaliyetlere katılımdır. Bu temada katılımcıların keyif aldıkları uğraşıları üzerinde durulmaktadır. Katılımcıların keyif aldıkları aktiviteler arasında "televizyon izlemek, tiyatroya veya halk konserlerine gitmek, dişarıda akrabaları veya arkadaşları ile yemek yemek, örgü örmek ve mutfak ișleri” bulunmaktadır. Katılımcıların çoğunluğu en keyif aldıkları aktivitenin telefonla görüșmek ve insanlarla konușmak olduğunu belirtirken bunun tam tersini söyleyen bir katılımcı da olmuştur.

"Bi tanidiklara telefon ediyom ondan sonra bastonumu elime allyorum. Kimi bulursam it gibi bi dedikodu ediyom, șarz oluyom. Sonra gelip örgüme ver ediyom." (K4, 67, Kadın)

"Telefon niye var? Haber vermek için, haberleșmek için. Oysa bugün genci yașlısı hepsi telefon ellerinde ya bakıyorlar (facebook $v b$ ) ya da saatlerce kulaklarında konuşuyorlar." (K7, 70, Erkek)

Genel olarak belirtilen aktiviteler dișında özellikle kitap okuma ve yabancı dil öğrenme gibi faaliyetlere önem verdiğini belirten bir katılımcı olduğu gibi gezmekten keyif aldığını belirten bir katılımcı da bulunmaktadır.

“...gerçi son zamanlarda bazen gözümle ilgili sıkıntılardan dolayı çok uzun okuyamasam da okumaya çalışıyorum kitap okumayı da seviyorum. Onun dișında düşündügüum gibi yașamaya çalıșıyorum. Sanat sayılır mI bilmiyorum, birtakım işte belediyenin açtı̆̆ kurslar, ahsap boyama vesaire onlara gidip gelmiștim, 2-3 yıl kadar da Ingilizce kursuna gittim." (K1, 74, Kadın)

"Gezmeyi seviyorum. Karadeniz turuna gittim, ta Batum'a kadar gittim gezdim. Geçen sene Antalyaya burdan çıktım, Antalya, Kaș, Manavgat, Kuşadası... gittim gezdim 15 gün. Ayağım ağrıyo oturayım diye düşünmem. Tarihi yerleri gezmeyi severim, müzeleri gezmeyi severim." (K2, 77, Kadın) 
89 yaşındaki bir kadın katılımcı ise yaşı nedeniyle sosyal ve kültürel faaliyetlerinin kısıtlandığını belirtmekte ve eski günlere olan özlemini şu şekilde ifade etmektedir:

\section{"Aile dostlarımız var ama benim yaşıtım kalmadı neredeyse. Eski arkadaşlarımın, dostlarımın aileleri var artık. Artık mezarlıklarda, hayatta olanlardan daha fazla sevdiğim var. Daha çok ailemle buluşuyorum. Birkaç tane altın günümüz var. Memleketten arkadasslarla, ailemle, apartmandan komşularla. EV gezmelerine gidiyoruz, orada sohbetler ediyoruz. Oralarda da daha çok eski günleri anıyoruz." (K10, 89, Kadın)}

Yaşı sebebiyle çoğu arkadaşının vefat ettiğini belirten katılımcı, kalan arkadaşları ve ailesiyle birlikte vakit geçirmeye devam ettiğini belirtmiştir. $\mathrm{Bu}$ anlamda eski ilişkilere duyduğu özlemi de dile getirmektedir. Verilen ifadeye bakıldığında İçli'nin (2010: 9) yapmış olduğu araștırma sonucunda da belirttiği gibi, yaşlılıkta ilişkilerin devamlılığı, miktarı ve kalitesi yaşl bireyleri moral ve duygusal anlamda olumlu yönde etkilemektedir.

Katılımcıların konser, tiyatro gibi kültürel faaliyetlere katılımları çok düşüktür. Bunun nedenini yaşlarının ilerlemiş olmasına, ekonomik ve bazı sağlık sorunlarının bulunmasına bağladıkları anlaşılmaktadır. Çoğunun tek eğlence kaynağının televizyon olduğunu ifade etmeleri ise, hem ekonomik bakımdan masrafsız olduğu gerekçesiyle hem de evdeki rahatlık açısından değerlendirilmektedir.

"Bizden geçti artık, bazı şeyler gürültü gibi geliyo, kafam kaldırmiyor, evim rahat." (K5, 70+, Erkek)

"Bazen hafta sonu akşam parkta halk konserleri oluyo onlara gidiyom ama akşam geç saatlere kadar duramıom ancak televizyonda izliyom" (K15, 65, Erkek)

Sözünü ettiğimiz katılımcıların ifadelerine bakıldığında, diğer ifadelere göre farklı aktivitelerden bahsettikleri görülmektedir. Çoğunluğu orta ve alt sınıfa mensup olan katılımcıların eğitimleri, yaşları, medeni durumları, çocuk sayıları ve gelir durumlarını tanımlamaları bakımından oldukça benzer yaşantıya sahip oldukları dikkat çekmektedir. Bourdieu'cu anlamda, katılımcıların edinmiş oldukları kültürel sermayenin benzerlikleri çerçevesinde beğeni tercihlerinin gelișmiş olabileceği düşünülmektedir. Bu aynı zamanda Görgün-Baran'ın (2008) çalışmasında bahsettiği gibi, tek bir yaşlılığın olmadığını ve kişilerin kültürel sermayelerine bağlı olarak yaşlanma döneminden beklentilerinin de farklı olabileceği konusunu hatırlatmaktadır. Dolayısıyla katılımcların farklı unsurlara bağlı olarak keyif almış oldukları aktivitelerinin farklılaşması olağan görünmektedir.

\section{SONUC}

Yaș almanın doğal ve kronolojik bir süreç olduğu fakat bir o kadar da sosyal ve kültürel olarak inşa edildiği bilinen bir gerçekliktir. Dolayısıyla yaşa atfettiğimiz anlamlar hem toplumsal hem de kültürel olarak öznel bir özellik taşımaktadır. Dünya Sağlık Örgütü (DSÖ) yaşam beklentisinin uzaması ve yaşlı nüfusunun artması karşısında yaşlılık sınıflamasını değiştirerek 65-74 yaş arasını genç, 75-79 arasını orta, 80 ve üzerini ise yaşlı olarak kabul ettiğini açıklamıştır. Bu şekilde yaşam sürecinin uzaması kuşkusuz bir imkân ve şans meselesidir. Dolayısıyla bu süreç bireyler açısından ne kadar çok olumlu yönde inşa edilirse o kadar pozitif, bașarılı ve aktif bir yașlanma dönemi geçirilmesine zemin hazırlanmış olur. Bunun iki önemli işlevi olduğu söylenebilir. Birincisi yaşlı bireyin yaşam sürecini üretken bir şekilde geçirmesine neden olur. İkincisi ise kuşaklararası deneyim aktarımında gelecek nesillerin daha sağlıklı yaşlanmalarına örnek teşkil eder ve katkı sağlanır. Yaşam sürecini sağlıklı bir biçimde geçirmek için bu çalışmada, katılımcıların sosyal sermaye ağlarının genişliği ile güven ilişkileri üzerinden yalnızlıklarını giderebilecekleri düşüncesiyle bu konunun araştırılması değerli bulunmuştur.

Araştırmada 65 ve üzeri yaştakilerin sahip oldukları sosyal sermaye ile yalnızlıklarını giderme arasındaki ilişkilere odaklanılmıştır. Araştırmanın teorik çerçevesini Coleman ve Putnam'ın sosyal sermeye ve güven ilișkileri, Bourdieu'nun kültürel sermaye ve De Jong Gierveld'in ve Wenger ve diğerlerinin üzerinde durduğu yalnızlık kavramları oluşturmaktadır. Araştırmanın amacı, katılımcıların sosyal sermayeye sahiplik düzeyi ile yalnızlıklarını gidermeyi nasıl anlamlandırdıklarını tespit etmeye yöneliktir. Bu kapsamda 65 yaş ve üzerindeki katılımcıların sahip olduğu sosyal sermayenin gündelik ilişkilerine nasıl yansıdı ğı, kimlerle birlikte oldukları, neler yaptıkları, topluma katılımları, gönüllü kuruluşlarla ilişkileri ve sosyal-kültürel faaliyetlere katılım çerçevesinde güven ve yalnızlı durumları keşfedilmeye çalışılmıștır. Araştırma, Ankara'da ikamet eden 9'u kadın, 7'si erkek olmak üzere toplam 16 kişiyle gerçekleștirilmiş ve maksimum çeşitlilik sağlanarak derinlemesine görüşmeler yoluyla veriler toplanmıştır.

Sosyal sermaye ağları, araștırmada kullanılan kuramcılar (Coleman ve Putnam) çerçevesinde aile ve akrabalık ilişkileri, arkadaşlık ve komşuluk ilişkileri ve bunlarla bağlantılı güven ilişkileri, gönüllü kuruluşlara ve derneklere katılım, sosyal-kültürel faaliyetlere katılım olarak sınıflandırılmıștır. Ayrıca Avrupa Aktif Yaşlanma Endeksinde yer alan topluma katılım adına yaşlı bireylerin yetişkinlere, çocuklarına ve torunlarına bakımı da dahil edilmiştir. De Jong Gierveld ve diğerleri (2006) yalnızlı̆̆ın, sosyal ilişki ağlarının zayıf olmasından kaynaklandığından söz ederken, Wenger ve diğerleri (1996) ise bireylerin arkadaşlarının bulunmasını ve onlarla güvenli ilişkilerin kurulmasını yalnızlığı gidermede önemli bir faktör olarak değerlendirir. Nitekim araștırmamızın sonuçları bu konuyu desteklemektedir.

Katılımcıların gündelik yaşamda deneyimledikleri aile, akrabalık ve komşuluk ilişkilerinin Coleman ve Putnam'ın teorilerini destekler nitelikte olduğu, ancak gönüllü kuruluşlara katılım ile politik katılım (yurttaşlık katılımı) konusunda seçimlerde oylarını kullanmanın dışında bir etkinliklerinin bulunmadığı bilgisi edinilmiştir. Dolayısıyla Putnam'ın sivil örgütlenmeler ve yurttaşlık katılımı konusu ile ve AAI'nın politik katılımı konusunda katılımcıların bir üyelik ve etkinlikleri bulunmadığı için köprü kurucu 
bağların gerçekleşmediği görülmektedir. Bu sonuç kuramın bu kısmının desteklenmediğine işaret etmektedir. Bunun nedenini katılımcılar, yaşlarının ilerlemesinden dolayı kendilerinin artık bir koşuşturma içerisinde olmalarının pek mümkün olmadığına bağlamışlardır. Bir kısmı ise torun bakımının ve komşuluk ilişkilerinin kendilerinin zamanını yeteri kadar aldığını ifade ederek başka bir faaliyete gerek kalmadığını belirtmișlerdir. Turner (2011:148) bu durumu, yaşlılık döneminin gündelik toplumsal sorunlardan uzaklaşmayı veya bu sorumluluklarının azalmasını sağlayan mazeretler üretmeye ve yaşlı olmayı edilgenlikle eş değer görme eğiliminde olmalarına bağlamaktadır. Bu konuda TÜSEV'in (2011:80), Türkiye'de Sivil Toplum: Bir Dönüm Noktası araştırmasında, 65 yaş üzeri vatandaşların \% 5 'in üzerinde olduğu ifade edilmekte ve yaşlıların sosyal katılımının $\% \quad 5$ düzeyde seyrederken siyasi katılımlarının \% 3'e düștüğü vurgulanmaktadır. Benzer bir sonuç Görgün-Baran ve diğerlerinin (2005) Ankara'da yaptıkları Yaşlılık ve Aile Ilișkileri araștırmasıyla da desteklenmektedir. Türkiye'de bireylerin gençlik ve yetişkinlik döneminde gönüllü ve sivil örgütlenmelerle kısmi bir biçimde ilișkilerinin olduğu görülmekte, yaşlılığın dinlenme ile eşdeğer anlaşılması ve yaşlıların ileri yaşlarda kendini sağlık açısından güçsüz hissetmesi yaşlılık döneminde topluma ve politik katılıma olan duyarlılığı azaltmaktadır. Bu durum, katılımcıların habitusu ile bağlantılı olarak gençlik ve yetişkinlik dönemlerinde sivil-gönüllü kurulușlarla bağlarının bulunmaması biçiminde yorumlanabilir. Oysa 2020 yılı itibariyle Türkiye'de yaşlıların doğrudan kendilerinin kurduğu dernekler aracilığı ile topluma katılım göstereceğine ilişkin örneklere rastlanmaktadır. Türkiye Emekliler Birliği, Üretken Bilge Yaşlılar Derneği, Yașlılık Platformu, Tazelenme Üniversitesi, vb. gibi kuruluşlarda görev alan 65 yaş ve üzeri bireyler aktif olarak yașamlarına anlam ve değer katmayı başarmaktadırlar.

Araștırmanın önemli bir sonucu olarak katılımcılar, yaşamdan kopmak yerine kendilerini dinlemekten kaçındıklarını, hastalıklarını fazla problem etmediklerini, torun baktıklarını hatta çocuklarına destek olduklarını belirtmişlerdir. Bir kısmının ise sosyal sermayesinin geniş olmasından dolayı yalnızlık konusunda şikâyet etmekten kaçındıkları hatta çocuklarına belli ettirmedikleri tespit edilmiștir. $\mathrm{Bu}$ durum Coleman'ın belirttiği gibi, yaşlı bireylerin rasyonel seçim kuramı çerçevesinde davrandıklarına işaret etmektedir.

Katılımcıların yașamlarında sosyal ilișkileri sayesinde aktif oldukları ve sosyal sermayelerinin geniş olduğu söylenebilir. Birçok çalışmada da benzer sonuçlarla karşılașılmıștır (Kalaycıoğlu vd., 2003:94; Canatan, 2016:148). Katılımcıların hemen hepsi aktif konumdadır ve iki katılımcı hariç diğerleri kendilerini yalnız hissetmediklerini belirtmişlerdir. Kendini yalnız hissedenler ise bunu açılkça söylemekten ziyade içsel bir duygu yaşadıklarını ve bunu yakınlarına hissettirmediklerini ifade etmişlerdir. İçsel duygunun yarattığı yalnızlık, kendi kendine yalnızlık çerçevesinde duygusal yalnızlığa göndermede bulunurken sosyal yalnızlık, ilişkilerin kurulamaması anlamına gelmektedir (Kalınkara \& Sarı, 2019; Saltan vd., 2018:196). Bizim çalışmamızda ise yaşlı katılımcıların sosyal sermayelerinin güçlü olmasına rağmen bazen, akşam tek başlarına kaldıkları zaman yalnızlık hissettikleri yönünde bir sonuca ulaşılmıștır. Başkalarıyla birlikte olurken dertlerini unutan ya da unutmuş gözüken yaşlılar yalnız kaldıklarında içlerini kaplayan hüznü ve burukluğu kendi başlarına yaşamaktadırlar. Onun için katılımcıların sürekli bașkalarıyla birlikte olmayı arzu etmeleri yalnızlıklarını giderici bir faktör olarak değerlendirilmekte ve sosyal sermaye sahipliğinin önemi ortaya çıkmaktadır. Dolayısıyla bu sonuç, De Jong Gierveld ve diğerleri ile Wenger ve diğerlerinin vurguladığı gibi yalnızlığın çaresinin sosyal ilişki ağlarının geniş olmasında aranması görüşü ile desteklenmektedir.

Araştırmadan elde edilen verilere göre 65 yaş ve üzeri katılımcıların çoğu sosyal sermaye ağlarının geniș olduğunu ve yalnızlıklarını gidermek için akrabalarıyla ve özellikle komşularıyla sık dokulu bir ilișki yașadıklarını, bu sayede yalnızlıklarını așmaya çalıştıklarını ifade etmişlerdir. Arkadaşlık ilişkilerinden çok kendi çocukları ve torunlarıyla kurmuş oldukları ilișkilerin doyuruculuğu üzerinde durmuşlardır. Yalnız iki katılımcı, çocuğu ile arasının çok iyi olmadığını ama torunları ile iyi anlaştıklarını ve onları çok sevdiklerini anlatmışlardır. Komşuluk ilişsilerinin sürdürülmesinde ise sosyo-ekonomik düzeyin etkili olduğu görülmektedir. Orta ve alt sosyoekonomik düzeydeki yaşlıların komșuluk ilișkilerini bir nevi arkadașlık ve dostluk ilișkisi gibi değerlendirdikleri ve birbirlerine gidip gelme, birlikte sohbet etme, parka gitme vb. durumların siklıkla gerçekleștirilerek zamanlarının çoğunu komşularıyla birlikte geçirdikleri anlaşılmıștır. Orta-üst sosyoekonomik düzeyde ise komşuluk ilișkilerinin modern kent yaşamında resmi boyuta büründügü görülmüș ve apartmanda karșılaștıklarında "merhaba, nasılsın?" demenin ötesinde kimseyi rahatsız etmemek için birbirlerine gidilip gelinmediğine katılımcılar tarafından işaret edilmiștir.

Öte yandan sosyal sermaye ile güven ilișkisine bakıldığında katılımcıların birincil ilişki kurdukları kişilere güven duydukları görülmekte, özellikle çocuklarının varlığını hayatlarındaki tek güvenceleri olarak gördüklerine kanıt oluşturmaktadır. Bu noktada kendisi için kızlarını güven kaynağı olarak gören katılımcının kızlarım benim hayatım ifadesi önemlidir. Genelde katılımcılar fiziksel olarak yakın ve sosyal olarak tanıdık olma ile birincil ilișki içindeki yakın sosyal çevredeki kişilere güven duyduklarını belirtmişlerdir. Katılımcıların aldatma veya kandırmanın aile içi ilişkilerde söz konusu olmayacağına inandıkları görülmektedir. Bu durumda yaşlı istismarına ve şiddetine yönelik bir endișe taşımamaları katılımcıların hayata olan bağlılığını artıran ve rasyonel seçimleri gereği iyi ilişkiler inşa etmeyi hedefleyen bir yapıda olduklarını göstermektedir. Aileyi değerli ve önemli bir kurum olarak gören katılımcılarımızın en çok güven ilişkisi geliştirdikleri yerin yakın sosyal çevreleri yani aileleri olduğu anlașılmıștır. Bazı katılımcılar yakınlarına hasta ya da sağlı sorunları olduğunda belli ettirmediğini belirtirken, bu mesajın aynı zamanda çocuklarını üzmek istemedikleri anlamına geldiğini 
göz ardı etmemek gerekir. Önemli bir sonuç da katılımcılardan köy kökenli olanlarının halen köyle olan bağlarını devam ettirmeleridir. Kalaycıoğlu ve diğerlerinin (2003) araştırmasında da benzer bir sonuç bulunmuştur. $\mathrm{Bu}$ durum yaşlı bireylerin geleneklerine ve alışkın oldukları topraklara aidiyet duyduklarını göstermekte, kışın Ankara'da yazın köylerinde olmaktan mutluluk duymaktadırlar. Bu husus ise hayata bağlılığın bir göstergesi olarak yorumlanabilir. Aslında bu araștırmada katılımcıları hayata bağlayan unsurun ister kentsel yaşamçekirdek aile isterse kırsal yaşam-geniș aile tipleri olsun aileleri, çocukları ve torunları olduğu görülmüştür. Bunun nedeni geçmişte kurulan güçlü aile ilişkilerinin ve güven duygusunun varlığıdır denilebilir. Ayrıca Bauman'ın da (2017) işaret ettiği gibi günümüzde her şeyin akıșkan hale gelmiş olması, anlık olarak yaşanan belirsizliğin yarattığı sorunlar ya da sosyal, siyasi ve ekonomik krizlerin getirdiği savaș, göç, güvensizlik, adaletsizlik, sağlık (covid-19 salgını), yoksulluk vb. gibi nedenler insanların kaygı ve endişe düzeylerini artırmakta ve aileyi güvenilecek, sığınılacak bir liman olarak görme eğilimlerini artırmaktadır. Kuşkusuz bu durum aile bağlarının güçlenmesiyle sorunun çözüldüğü anlamına gelmemektedir. Ama biraz önce sıralanan bu nedenler bazen aile içi ilișkilerde șiddetin artmasında ve her türlü şiddet olaylarının kamusal mekanlara taşınmasında kendini göstermektedir. Tüm bunlara rağmen yeni nesil için artık aile kavramından çok ev yaşamı kavramı önemli hale geliyor, diye düşünebilir. $\mathrm{Bu}$ çalışmada maddi manevi her şeyini paylaşan, sevilen ve güvenilen insanlarla birlikte olmak, bunun için rasyonel tercihler yapmak, kișisel bir karar olarak kendini sorumlu tutmak anlayıșının da geliştiği bir gerçek olarak karşımıza çıkmaktadır. Özellikle çocukları ile ilișkileri bozuk olan katılımcıların hoşgörülü olması kuşaklararası çatışmanın güven yoluyla aşıldığını da ortaya koymaktadır. Ailenin önemli olduğu sıklıkla vurgulanmasına rağmen şiddetin yine aile içinde olması ilginç bir durumdur. Aile içi şiddetin arttığına ilişkin veriler dikkate alındığında şiddetin daha çok genç-yetişkin yaşlarda görülmesi, yaşlıların çatışma istemedikleri biçiminde de yorumlanabilir. Ancak şiddet konusunun yalnızca yaş faktörüne bağlanamayacağını belirtmek gerekir.

Coleman'ın belirttiği bireysel ve kolektif ilișkilerle kurulan köprü meselesinde katılımcıların aile ilişkilerini bireysel; akrabalık, komşuluk ve kurumlarla olan ilişkilerini ise kolektif ilişkiler olarak değerlendirdiğimizde, köprü kurma konusunda yetenekli oldukları görülmektedir. Putnam açısından aile, yakın akraba ve komşuluk ilişkileri bağlayıcı sosyal sermayeye işaret etmesi açısından araştırmada önemli bir yer işgal etmektedir. Ancak Putnam'ın fiziksel mesafe olarak uzak akraba ilișkilerini, kaybedilmiş olan arkadaşlık ve iş arkadaşlığını ve yurttaş katılımını gerektiren gönüllü-sivil kuruluşlara katılımı konusunda araştırmamıza katılanlar açısından köprü kuran sosyal sermaye özelliğini taşımadığı görülmektedir. Bu açıdan araștırmamızda yalnızca bir katılımcının deneyimlediği iş arkadaşlığı ve bir katılımcının da akrabasıyla yılda bir kez görüşerek oluşturduğu bağ hariç, diğerlerinin (iş) arkadaşlıklarının olmadığı dikkate alınırsa köprü kuran sosyal sermaye ayağının bulunmadığı görülür.
Bunu da katılımcıların ileri yaşlarına ve arkadaşlarının kayıplarına bağlamak mümkündür.

Sonuç olarak, sosyal sermaye ağlarını genișletmenin ve güvenli ilișkiler kurmanın çocukluktan itibaren atılan adımlarla ilgili olduğunu belirtmek gerekir. Bireylerin birbirleriyle olan ilișkilerini sağlıklı ve olumlu bir biçimde geliştirmenin yolu emek vermekten ve mücadele etmekten geçmektedir. Birey olarak sosyal ilişkilerin geçmișten getirilen kültürel alışkanlıklarla, Bourdieucu anlamda habituslarla ve sosyo-ekonomik düzey ile ilişkili olduğunu, bu nedenle benzer özelliklere sahip kişilerle arkadaşlık kurulduğunu dikkate alırsak bu ilișkilerin bireyin kendi rasyonel seçimleriyle alakalı olduğu söylenebilir. Yalnızca aile yakınlarıyla değil, okul ve iş yerindeki arkadaşlıklar için de özenli davranmak, açık iletişim ve empati kurmak hem insani bir davranış hem de demokrasinin özgürlük ve eșitlik ilkelerinin bir gereği olarak görülmelidir. Bu konuda yerel yönetimlere ve hükümetlere düşen görev, yaşlı bireyler için rekreasyon alanlarının tesis edilmesi ve götürülecek sosyal ve kültürel hizmetler için özelikle hükümetlerin sosyal devlet anlayıșı ile hareket etmesidir. Ayrıca yaşlı vatandaşlara birer kültürel bellek olarak değer verilmesi, sağlık ve sosyal güvenlik hizmetlerinin geliștirilmesi yoluyla yaşlı vatandaş ile devlet arasında bir güven ilişkisinin kurulması sağlanabilir. $\mathrm{Bu}$ bağlamda sosyal sermayenin ileri yaşlarda bireye en büyük katkısı; sosyal ortamlarda bulunarak sosyalleşmeyi, insanlarla iletişim kurmayı, toplumsal yarar sağlamayı, çevresindeki olup bitenlerden haberdar olmayı, güven içinde yaşamayı, yalnızlığı gidermeyi ve tüm bu hususları bir araya getirmeyi ifade eden hayatı anlamlandırmayı sağlamasıdır.

\section{ÇIKAR ÇATIŞMASI}

Yazarlar tarafından herhangi bir çıkar çatışması beyan edilmemiştir.

\section{KAYNAKÇA}

Allan, K. (2006). Contemporary Social and Sociological Theory: Visualizing Social Words. California: Thousand Oaks, Pine Forge Press.

Aydemir, M. A. (2011). Toplumsal İlişkilerin Sosyal Sermaye Değeri - Topluluk Duygusu ve Sosyal Sermaye Üzerine Bir Araștırma. Selçuk Üniversitesi SBE Sosyoloji Anabilim Dalı, (Doktora Tezi), Konya.

Aydemir, M. A., \& Tecim, E. (2012). Türk toplumunda aile ve dinin sosyal sermaye potansiyeli. Selçuk Üniversitesi Sosyal Bilimler Enstitüsü Dergisi, 2012(28), 43-59.

Bauman, Z. (2017). Akışkan Modernite. (Çev., S. 0. Çavuş), İstanbul: Can yayınları.

Canatan, A. (2016). Yașlılıkta sosyal ilișkiler ve kuşaklararası etkileşim. Ceylan, H. (Ed.) İç: Yaşlılık Sosyolojisi. Ankara: Nobel Akademik Yayıncilık. (s.139-156).

Cohen, D., \& Prusak, L. (2001). In Good Company: How Social Capital Makes Organizations Work. Boston: Harvard Business School Press. 
Danış, M. Z. (2005). Türkiye'de yaşlı nüfusun yalnızlık ve yoksulluk durumları ve sosyal hizmet uygulamaları açısından bazı çıkarımlar. Toplum ve Sosyal Hizmet, 20(1), 67-84.

De Jong Gierveld, J. (1998). A review of loneliness: Concept and definitions, determinants and consequences. Reviews in Clinical Gerontology: Netherlands Interdisciplinary Demographic Institute (NIDI), 8, 73-80.

De Jong Gierveld, J., \& Van Tilburg, T. G. (2006). Loneliness and social isolation. In: D. Perlman \& A. Vangelisti (Eds.). The Cambridge Handbook of Personal Relationships, Cambridge, UK, (pp. 485-500).

Ekși-Uğuz, H. (2010). Sosyal Sermaye, Kișisel ve Kurumsal Gelişmeye Farklı Bir Yaklașım. Ankara: Orion Kitabevi.

European Commission (2015). Active Ageing Index 2014: Analytical Report. Report prepared by Asghar Zaidi of Centre for Research on Ageing, University of Southampton.

Field, J. (2008). Sosyal Sermaye. (Çev., Bahar Bilgen, Bayram Şen). İstanbul: Bilgi Üni. Yayınları.

Gökler-Danıșman, I., \& Aydın, G. (2011). Huzurevinde yaşayan yaşlıların benlik-algılarının yordanmasında sosyodemografik özellikler ve algılanan sosyal desteğin rolü. Aile ve Toplum Dergisi, 07(24), 69-91.

Görgün-Baran, A. (2008). Yaşlılıkta sosyalizasyon ve yaşam kalitesi. Yaş̧ı Sorunları Araştırma Dergisi (YSAD), 1(2), 86-97.

Görgün-Baran, A. (2016). Yaşlılıkta sosyal izolasyon ve yalnızlık, H. Ceylan (Ed.), Yaşlılık Sosyolojisi, 1.Baskı, Ankara: Nobel Akademik Yayıncılık. (s.77-97).

Görgün-Baran, A. (2018). Ageism: Yaş ve yaşlı ayrımcılığı. H. Ceylan (Ed.), Kırgızistan'daki Gençlerin Yaşlılara Yönelik Tutumları. Bișkek: BRY Publish Housing.

Görgün-Baran A., Kalınkara, V., Aral, N., Akın, G., Baran, G., \& Özkan, Y. (2005). Yaşlı ve Aile İlişkileri: Ankara Örneği. Ankara: T.C. Başbakanlık Aile ve Sosyal Araștırmalar Genel Müdürlüğü Yayınları.

Görgün Baran, A. \& Kurnaz, Z. (2019). Yașlıların sosyo-ekonomik düzeylerine göre sosyal ilișkilerinin aktif yașlanma açısından analizi. N. Akdemir (Ed.), Geriatri ve Gerontolojiye Disiplinlerarası Yaklaşım. 1.Baskı, Ankara: Türkiye Klinikleri. (s. 39-47).

İçli, G. (2010). Yaşlılar ve yașlılı̆̆ın değerlendirilmesi: Denizli ili üzerine niteliksel bir araștırma. Yaş̧ı Sorunları Araștırma Dergisi (YSAD), 3(1-2), 113.

Kaçan-Softa, H. Bayraktar, T., \& Uğuz, C. (2016). Yaşlı bireylerin algilanan sosyal destek sistemleri ve sağlıklı yaşam biçimi davranıșlarını etkileyen faktörler. Yaşlı Sorunları Araştırma Dergisi (YSAD), 9(1), 1-12.

Kaçan-Softa, H. Ulaș-Karaahmetoğlu, G. Erdoğan, O., \& Yavuz, S. (2015). Yaşlılarda yaşam doyumunu etkileyen bazı faktörlerin incelenmesi. Yaşlı Sorunları Araştırma Dergisi (YSAD), 8(1), 12-21.

Kalaycıoğlu, S., Tol, U. U., Küçükkural, Ö., \& Cengiz, K. (2003). Yaşlılar ve yaşlı yakınları açısından yaşam biçimi tercihleri. TÜBİTAK Raporu, Ankara.

Kalınkara, V., \& Sarı, İ. (2019). Yaşlılarda sosyal ağ kullanımı ve yalnızlık ilişkisinin belirlenmesi. Yaşlı Sorunları Araștırma Dergisi (YSAD), 12(1), 8-19.

Karaağaç, G., Bayık Temel, A., \& Yıldırım, G. (2019). Gençlerin yaşlılığa ilişkin görüş ve düşüncelerinin incelenmesi, Yaşlı Sorunları Araştırma Dergisi (YSAD), 12(1), 32-41.

Korporaal, M., Van Tilburg, T. G., \& Van Groenou, M. I. (2008). Effects of own and spousal disability on loneliness among older adults, Journal of Aging and Health, 20(3), 306-325.

Kurtkapan, H. (2019). Yaşlılar için bir sosyal sermaye kaynağı olarak emekli dernekleri: İstanbul örneği. Muhakeme Dergisi, 2(1), 72-82.

Loas, E. (2018). The organizational use of online stock photos: The impact of representing senior citizens as eternally youthful. Human Technology, 14(3), 366-381.

Özkul, M., Kalaycı, I., \& Aslan, A. (2017). Yaşlılık ve kadın sorunlarını toplumsal sermaye perspektifinden düșünmek. Süleyman Demirel Üniversitesi Sosyal Bilimler Enstitüsü Dergisi, 2(27), 366-386.

Saltan, A., Kandemirtaş-Küçük, M., \& Mert-Boğa, S. (2018). Yaşlı bireylerde yaşanılan yer ile yalnızlık durumu arasındaki ilișkinin araștırılması. Yașam Becerileri Psikoloji Dergisi, 2(4), 191-198.

Solano, C. H. (1986). People without friends: Loneliness and its alternatives. In: Derlega, V. J., \& Winstead, B. A. (eds). Friendship and Social Interaction. Springer Series in Social Psychology, Newyork.

TÜSEV (2011). Türkiye'de sivil toplum: Bir dönüm noktası CIVICUS Uluslararası Sivil Toplum Endeksi Projesi (STEP) Türkiye Ülke Raporu II. TUSEV Yay. No. 51. İstanbul: Uzerler Matbaacilık.

Tufan, İ. (2014). Türkiye'de Yaşhllığın Yapısal Değişimi. İstanbul: Koç Üniversitesi Yayınları.

Turner, B. S. (2011). Tibbî Güç ve Toplumsal Bilgi. (Çev.: Ü. Tatlıcan), Bursa: Sentez Yayıncılık.

Weiss, R. S. (1973). Loneliness: The Experience of Emotional and Social Isolation. Cambridge: The MIT Press.

Wenger, G. C., Davies, R. Shahtahmasebi S., \& Scott, A. (1996). Social isolation and loneliness in old age: Review and model refinement. Ageing and Society, 16, 333-358.

Vincent, J. (2014). Küresel ekonomi-politiğin yeni biçimleri ve yaşlanan toplumlar. İç: N. Korkmaz \& S. Yazıcı (eds.), Küresellessme ve Yașlılık, Eleștirel Gerontolojiye Giriș. Ankara: Ütopya Yayınevi. (s. 92-134). 